\title{
Tectono-Sedimentary Evolution of the Uranium Deposits of the Dasa Graben, Northern Niger
}

By Abdoulwahid Sani, Moussa Konaté, Peter Wollenberg \& A. D. Christophe

Abstract- This study presents the structural evolution of the $\mathrm{N70}$ trending Paleozoic-Mesozoic DASA graben, which is considered a sub-basin of the Tim Mersoï basin, and is located in northern Niger. The DASA graben is a uranium-rich trough discovered in recent exploration surveys.

A tectono-sedimentary analysis of the DASA graben was implemented with a combined use of satellite imagery, field observations, borehole data analysis and available literature. This graben was affected from the Carboniferous to the Early Cretaceous by two major tectonic periods. The first period was an uplifting stage, which prevailed during the Carboniferous-Permian times and the second, ranging from the Triassic to the Early Cretaceous, corresponds to a rifting episode. The particularity of the DASA graben is that the sediments contain very high uranium grades. Lithological and tectonic factors controlled the emplacement of the uranium mineralization in the graben. The successive fracturing phases that affected the DASA graben were associated with a greater circulation of hydrothermal fluids and would have favoured higher grades of uranium mineralization.

Keywords: DASA graben, tectono-sedimentary, uplifting stage, rifting stage, uranium deposits.

GJSFR-H Classification: FOR Code: 260199

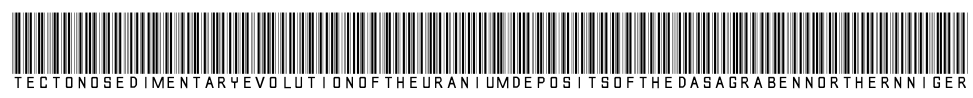

Strictly as per the compliance and regulations of:

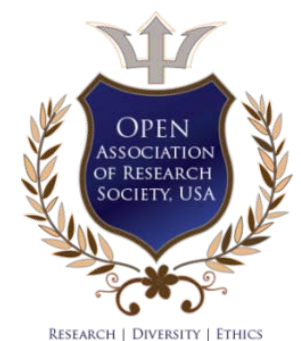

(C) 2021. Abdoulwahid Sani, Moussa Konaté, Peter Wollenberg \& A. D. Christophe. This is a research/review paper, distributed under the terms of the Creative Commons Attribution-Noncommercial 3.0 Unported License http://creativecommons. org/licenses/by-nc/3.0/), permitting all non commercial use, distribution, and reproduction in any medium, provided the original work is properly cited. 


\title{
Tectono-Sedimentary Evolution of the Uranium Deposits of the Dasa Graben, Northern Niger
}

\author{
Abdoulwahid Sani ${ }^{\alpha}$, Moussa Konaté ${ }^{\sigma}$, Peter Wollenberg ${ }^{\rho} \&$ A. D. Christophe ${ }^{\omega}$
}

Abstract- This study presents the structural evolution of the N70 ${ }^{\circ}$ trending Paleozoic-Mesozoic DASA graben, which is considered a sub-basin of the Tim Mersoï basin, and is located in northern Niger. The DASA graben is a uranium-rich trough discovered in recent exploration surveys.

A tectono-sedimentary analysis of the DASA graben was implemented with a combined use of satellite imagery, field observations, borehole data analysis and available literature. This graben was affected from the Carboniferous to the Early Cretaceous by two major tectonic periods. The first period was an uplifting stage, which prevailed during the Carboniferous-Permian times and the second, ranging from the Triassic to the Early Cretaceous, corresponds to a rifting episode. The particularity of the DASA graben is that the sediments contain very high uranium grades. Lithological and tectonic factors controlled the emplacement of the uranium mineralization in the graben. The successive fracturing phases that affected the DASA graben were associated with a greater circulation of hydrothermal fluids and would have favoured higher grades of uranium mineralization.

Keywords: DASA graben, tectono-sedimentary, uplifting stage, rifting stage, uranium deposits.

\section{INTRODUCTION}

L ocated on the western side of the Air Mountains, the Tim Mersoï basin is well known for its uranium mineralization hosted in Carboniferous and Jurassic formations. This basin is located in the northeastern part of the much larger lullemmeden basin (Fig. 1). It is limited to the west by the In Guezzam Ridge and to the east by the Air Mountains. Towards the north, it penetrates into the Hoggar Massif in Algeria where it is known as the syncline of Tin Séririne (Fig. 1) (Moussa, 1992, Konaté et al., 2007).

Recent exploration surveys have discovered a highly mineralized graben, the Dajy Surface Anomaly (DASA) which is the object of this study. It is positioned between the Arlit uranium mining area to the North and the Anou-Araren coal trough to the South (Fig. 1). The main purpose of this study is to determine the factors that favored uranium concentrations in the DASA graben.

Corresponding Author a: Abdoulwahid SANI.e-mail: ahidsani@yahoo.fr Author o: Moussa KONATE. e-mail: konate.moussa@gmail.com Author p: PeterWOLLENBERG. e-mail: peter.wollenberg@gmail.com Author W: Abdoulaye Din CHRISTOPHE.e-mail: abcdin76@yahoo.fr

\section{il. Geological Setting}

The geological history of the Tim Mersoï basin begins early during the Cambrian in the Tin Séririne Syncline (Joulia, 1959). Subsequently, the sedimentation areas moved southward, resulting in the deposition of continental and marginal-littoral detrital formations ranging from Cambrian to Miocene (Fig. 1). Along the western edge of the Air, these detrital formations exhibit stratigraphic levels (Fig. 1) from the Devonian to the Jurassic (Clermonté et al., 1991; Moussa, 1992). The Tim Mersoï basin is characterized by detrital infilling, resting unconformably on the pre-Cambrian basement (Fig. 1). The basin was infilled during three successive cycles: Carboniferous, Permo-Triassic to Jurassic and Lower Cretaceous.

The Lower Cretaceous cycle is represented by clayey to sandy- floodplain deposits extending from the west to the center of the previous deposition area, which was gradually rising (Forbes 1989, Clermonté et al., 1991).

According to Tauzin (1981), several brittle deformations affected the sedimentary infilling. Three main faults directions have been recognized:

a) The $\mathrm{NO}^{\circ}$ trending lineament of In-Azaoua-Arlit and the $\mathrm{N} 30^{\circ}$ trending fault system of Madaouéla. All of the exploited uranium deposits are located in the eastern part of the Arlit Fault, but uranium deposits have also recently been discovered on the western side, (Mamane Mamadou, 2016).

- The $\mathrm{N} 30^{\circ}$ fault system. It is expressed some time in the sedimentary cover in the form of flexures, which axes are spaced twenty kilometers apart. The most important $\mathrm{N} 30^{\circ}$ trending fault systems in the Tim Mersoï basin are those of Madaouéla (sector of Arlit) and the Adrar-Emoles (sector of DASA).

b) The $\mathrm{N} 130^{\circ}$ to $\mathrm{N} 140^{\circ}$ trending faults represent the main fault system that affect the Air Mountains. In the sedimentary series, these directions are well expressed. The Arlit fault is associated with several ${\mathrm{N} 150^{\circ}}^{\circ}$ striking faults in the Arlit mining area (Mamane Mamadou, 2016).

c) The $\mathrm{N} 70^{\circ}$ to $\mathrm{N} 80^{\circ}$ trending faults cut the basement intensively and also spread into the sedimentary cover and deposits. The $\mathrm{N} 70^{\circ}$ faults are reactivated in dextral strike-slip movements during the Upper Cretaceous (Guiraud et al., 1981). At the regional

.

.


scale, the $\mathrm{N} 70^{\circ}$ trending fault network plays a faultdamping role on the N30 faults (Gerbeaud, 2006).

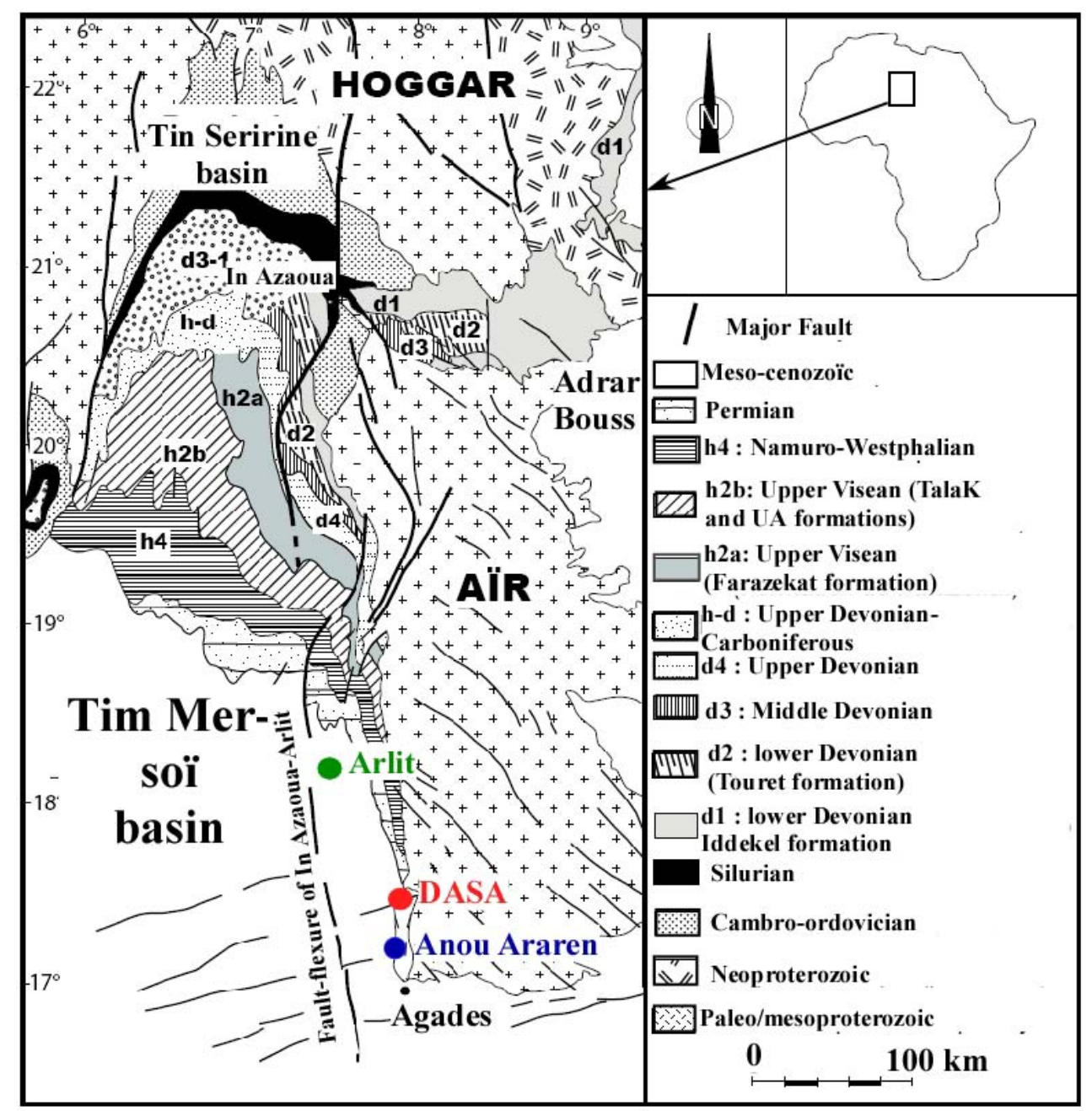

Fig. 1: Location and synthetic geological map of the Tim Mersoï basin (Greigert and Pougnet, 1965, modified)

The DASA graben is located in the Adrar Emoles 3 permit (location in Fig. 2), which covers an area of $121.3 \mathrm{~km}^{2}$. 


\begin{tabular}{|c|c|c|c|c|}
\hline Series in Age & Formations & \begin{tabular}{|c|} 
Litholo \\
-gy
\end{tabular} & \begin{tabular}{c|} 
Total \\
Thickness $(\mathrm{m})$ \\
\end{tabular} & \begin{tabular}{|c|}
$\begin{array}{c}\text { Sedimentation } \\
\text { time }(\mathrm{Ma})\end{array}$ \\
\end{tabular} \\
\hline \multirow{3}{*}{ Lower Cretaceous } & TEGAMA & & 1300 & \multirow{19}{*}{$246 \mathrm{Ma}$} \\
\hline & IRHAZER & & & \\
\hline & ASSAOUAS & & & \\
\hline \multirow{3}{*}{ Jurassic } & TCHIREZRINE2 & $\because 1$ & & \\
\hline & ABINKY & & & \\
\hline & TCHIREZRINE1 & & & \\
\hline \multirow{3}{*}{ Triassic } & MOUSSEDEN & & & \\
\hline & TELOUA 2-3 & & & \\
\hline & TELOUA 1 & & & \\
\hline \multirow{3}{*}{ Permian } & $\begin{array}{l}\text { Aokare } \\
\text { MORADI }\end{array}$ & & & \\
\hline & $\begin{array}{c}\text { TAMAMAIT } \\
\text { TEJIA }\end{array}$ & & & \\
\hline & IZEGOUANDE & $8:$ & & \\
\hline \multirow{7}{*}{ Carboniferous } & $\begin{array}{c}\text { Arlit } \\
\text { MADAOUELA }\end{array}$ & & & \\
\hline & TARAT & & & \\
\hline & TCHINOZOGUE & & & \\
\hline & GUEZOUMAN & & & \\
\hline & Akokan & rese & & \\
\hline & TALACH & & & \\
\hline & TERAGH & 8 & 0 & \\
\hline Basement & & & & \\
\hline
\end{tabular}

Fig. 2: Lithostratigraphiccolum of the Tim Mersoï Basin

From a stratigraphic point of view, all the sedimentary series observed in the Tim Mersoï basin are also represented in the DASA area. These are Carboniferous, Permian, Triassic, Jurassic and Cretaceous series, (Fig. 3). The main faults observed in the DASA graben are the Azouza fault which mark the border of the trough, the Adrar-Emoles $\mathrm{N} 30^{\circ}$ striking fault, and secondary faults $\mathrm{N} 130^{\circ}$ to $\mathrm{N} 150^{\circ}$ trending and E-W striking, (Fig. 3). 


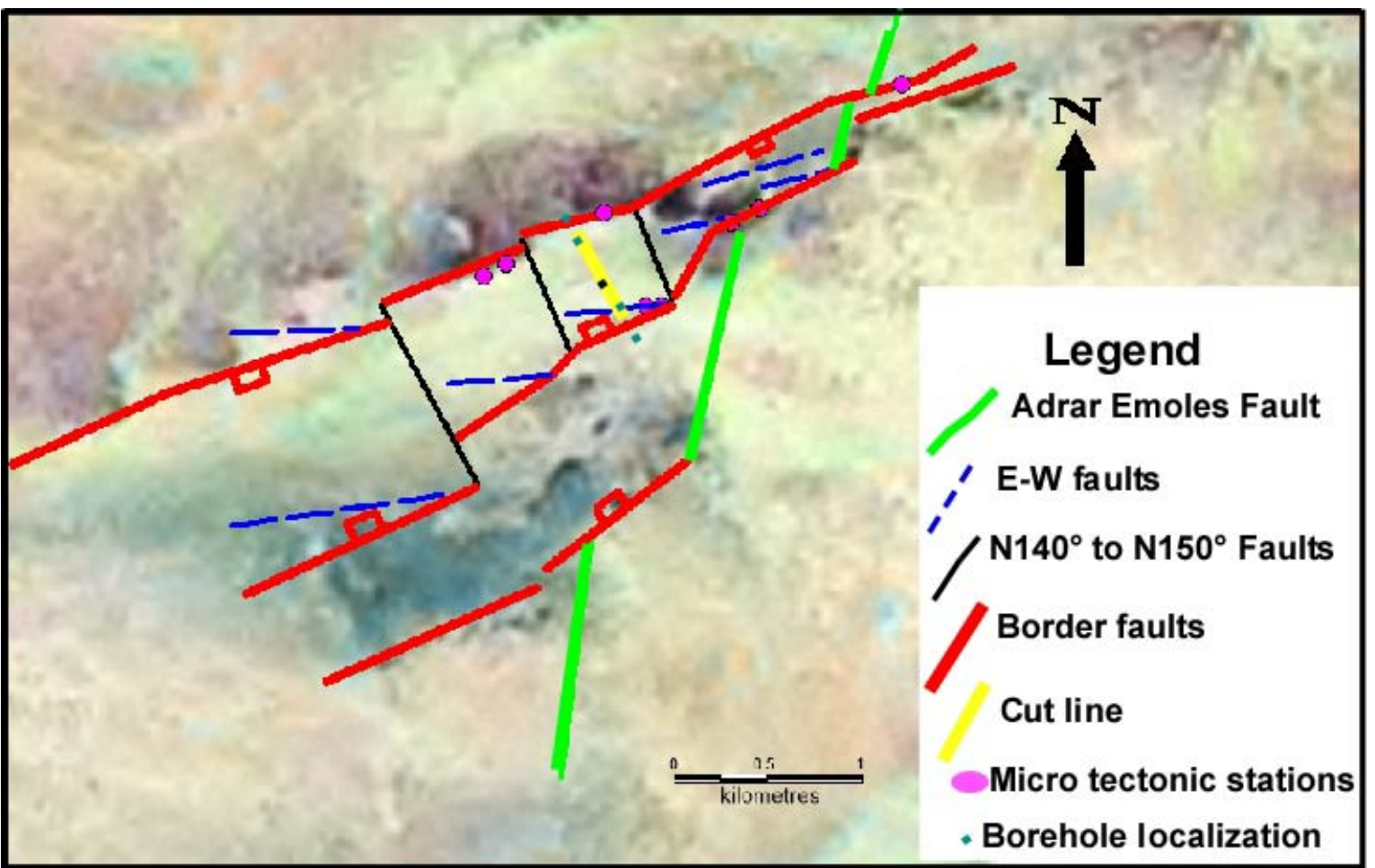

Fig 3: Synthetic representation of the main tectonic structures of the DASA graben

The DASA graben has the same orientation as the Carboniferous coal troughs of the Anou-Araren region, (Fig. 1). These coal troughs are limited by two major $\mathrm{N}^{\circ} 0^{\circ}$ trending dextral strike-slip faults: the Isokenwali fault in the northern part and the Aboye fault in the southern part. These two faults belong to the

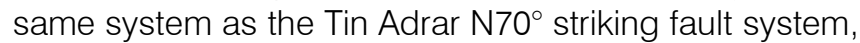
which is well represented in the Arlit region (Wright, 1989). Most of the work carried out in the Tim Mersoil basin has focused on the tectono-sedimentary evolution of the Tim Mersoï basin and the uranium metallogeny (Valsardieu, 1971, Sempéré, 1981, El Hamet, 1983, Forbes, 1989, Moussa, 1992, Wagani, 2007, Konaté et al., 2007, Mamane Mamadou, 2016).

\section{ili. Materials and Methods}

In this study, a multidisciplinary approach involving various tools (e.g., seismic profiles, satellite images, drill cores), software (e.g., Maplnfo 11.5, Surfer 11, Canvas 11) and various techniques (e.g., seismic interpretation, well logs correlation, micro tectonic and geochemical investigation) have enabled to:

(1) Make a tectono-sedimentary analysis;

(2) Determine the spatial arrangement of the uranium deposits;

(3) Characterize the basin geometry.

\section{Results}

a) Geological Setting of the Study Area

The DASA graben is bounded by faults systems which have controlled the graben structures. Within the
DASA graben itself, different directions of secondary faults affected the sedimentary infilling. These are $\mathrm{N} 30^{\circ}$, $\mathrm{N} 130^{\circ}$ to $\mathrm{N} 150^{\circ}$ and $\mathrm{E}-\mathrm{W}$ trending faults (Fig. 3).

In the DASA graben, the sedimentary succession has been studied through drilling data obtained during the uranium exploration work. The sedimentary rocks overlying the granitic crystalline basement consist of Devonian to Early Cretaceous series, which are described in the stratigraphic column of the study area (Fig. 4). The sedimentary infilling of the DASA graben is subdivided into five (5) series. These are: Terada series, Tagora series, Permian series, Agades series and Irhazer series (Fig. 4). To better understand the spatial arrangement of the DASA graben infilling, a structural cross-section is provided (Fig. 5) using field observation, well log and borehole data. 


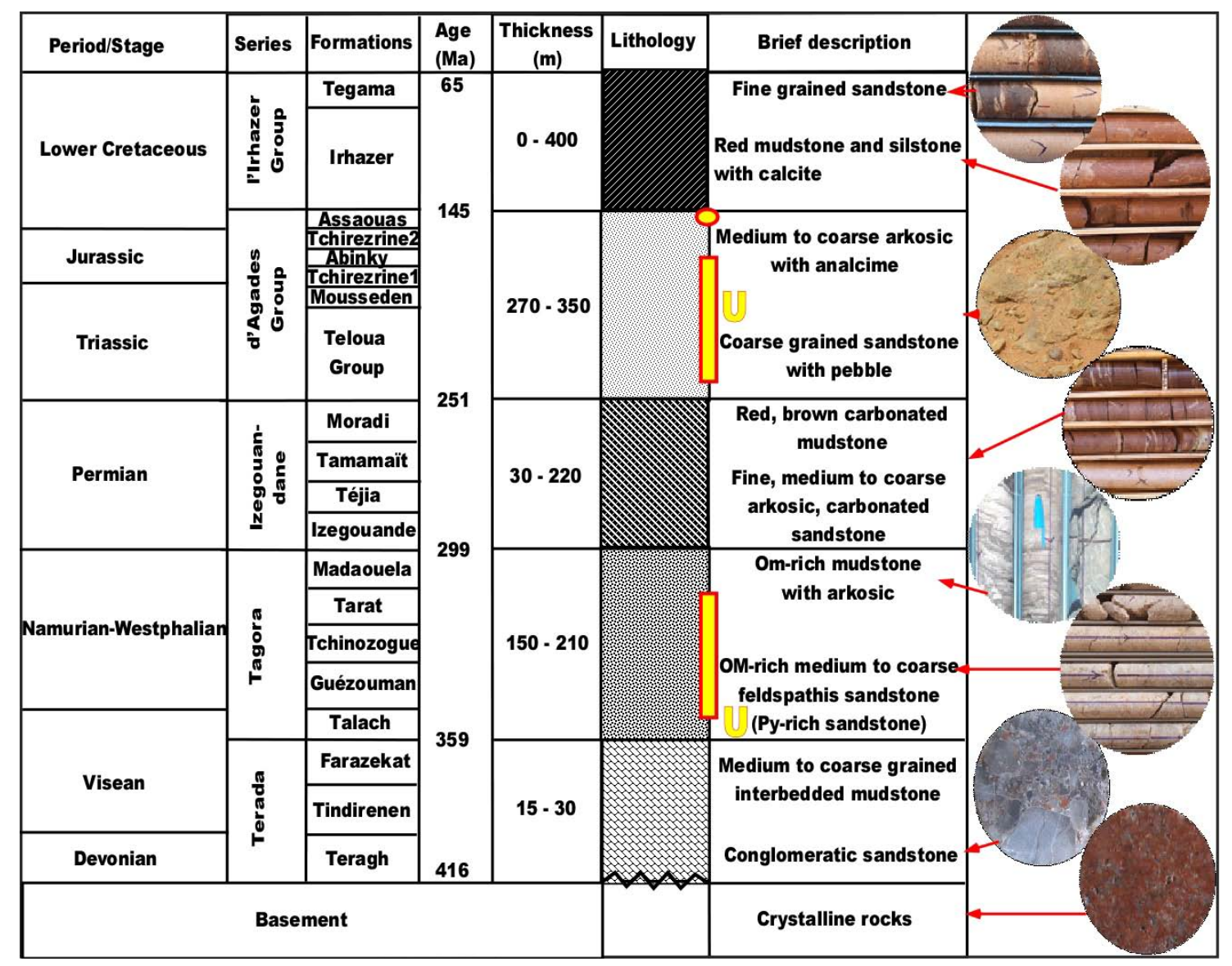

Fig. 4: Lithostratigraphic column of the DASA graben

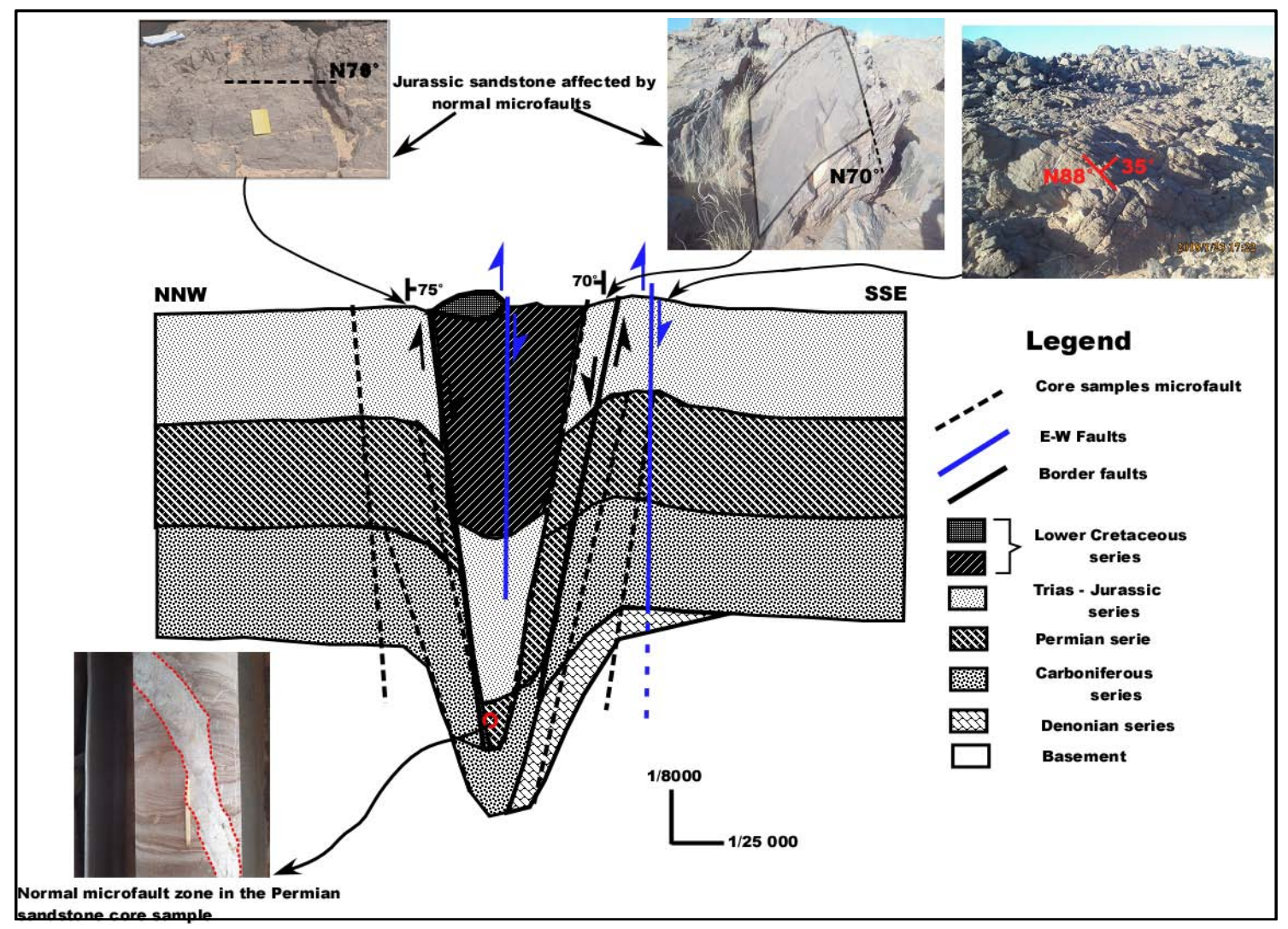

Fig. 5: DASA grabencross section 


\section{b) Lithostratigraphic Analysis}

A detailed study of the DASA graben drill core samples show highly heterogeneous formations. From the bottom to top the following formations have been distinguished:

\section{i. Crystalline Basement}

The samples ASDH525-02 and ASDH526-02 from two different boreholes were analyzed. The granitic rocks exhibit granular textures, the quartz shows partial resorption (possibly due to silicic alteration), and feldspars crystals are variably altered. Sample ASDH525-02 is fine to medium-grained granite and is dominated by quartz (73\%), K-feldspars (20\%) and plagioclase (7\%). It exhibits a granular, holocrystalline texture (Figs. 6A1 and A2) while sample ASDH526-01 is fine to medium-grained granite and is dominated by $\mathrm{K}$ feldspars (44\%), quartz (34\%) and plagioclase (22\%) (Figs. 6B1 and B2). The big quartz and feldspar crystals are cemented with a fine-grained matrix of the same minerals and mica. Fine-grained quartz and the matrix also appear as rock fragments in the sample. However, the matrix seems to replace quartz and feldspars in other places. This might indicate that the granite could be affected by hydrothermal alteration and could also be contaminated by rock fragments.
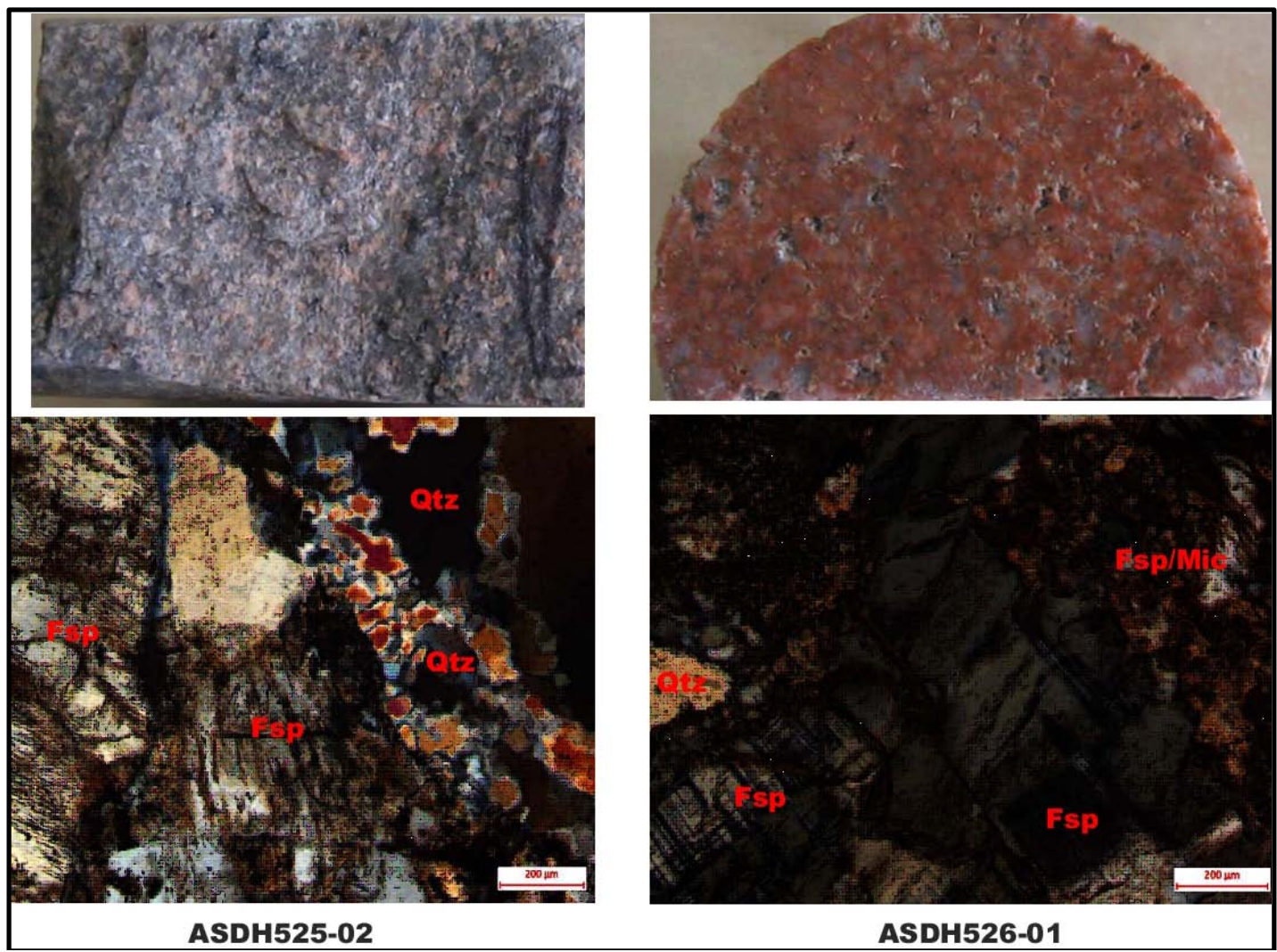

Fig. 6: Core samples and thin-section characteristics of the DASA basement

\section{ii. Devonian}

It mostly consists of poorly sorted coarsegrained sandstones with gravels of various sizes of the Teragh formation. Two samples taken from one borehole (ASDH526) were analyzed (Figs. 7A and B). The samples are dominated by quartz (89\%), Kfeldspars (8\%) and plagioclase (3\%) (Fig. 7C). The grains are cemented by a fine-grained matrix of quartz, feldspar and clay. The Devonian sandstones which are porous in the Tim Mersoï basin become well compacted in the DASA area, suggesting that the original texture was modified by hydrothermal fluid flows. 


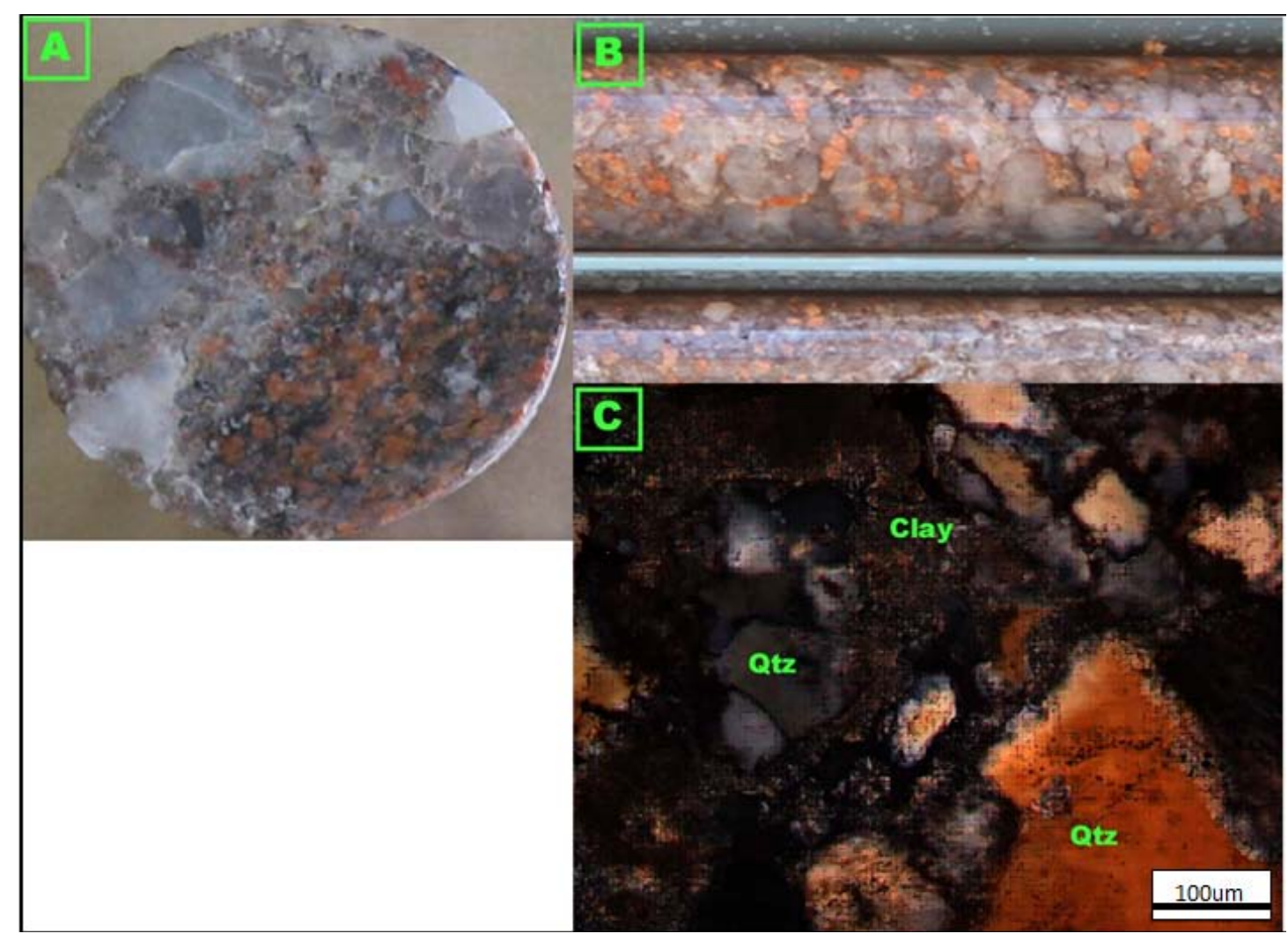

Fig. 7: Core samples and thin-section characteristic of the Teragh formation of the DASA graben ( $\mathrm{A}$ and $\mathrm{B}$ Teragh formation; $\mathrm{C}=$ thin-section of Teragh)

\section{iii. Carboniferous}

This consists of three Lower Carboniferous and two Upper Carboniferous formations subdivided into two sub-groups. These terrains correspond to higher Visean to Namuria to Westphalian.

a. The Lower Carboniferous (Visean To Namur)

Three stratigraphic units have been distinguished (Fig. 8 and 9).

1. The marine Talak formation (Visean) corresponds to black shale (Figs. 8A and 9A) ;

2. The fluvio-deltaic Guézouman formation (Namur) consists of medium to coarse feldspathic greyish sandstone (Figs. 8B and 9B). Towards the top, this formation exhibits an alternation of fine grained sandstone and black clay (Figs. 8C and 9C). These alternations display thickness and facies variations;

3. The marine to lacustrine Tchinézogue formation (Namur) is predominantly made up of greyish clayey fine grained sandstone (Figs. 8D and 9D). 

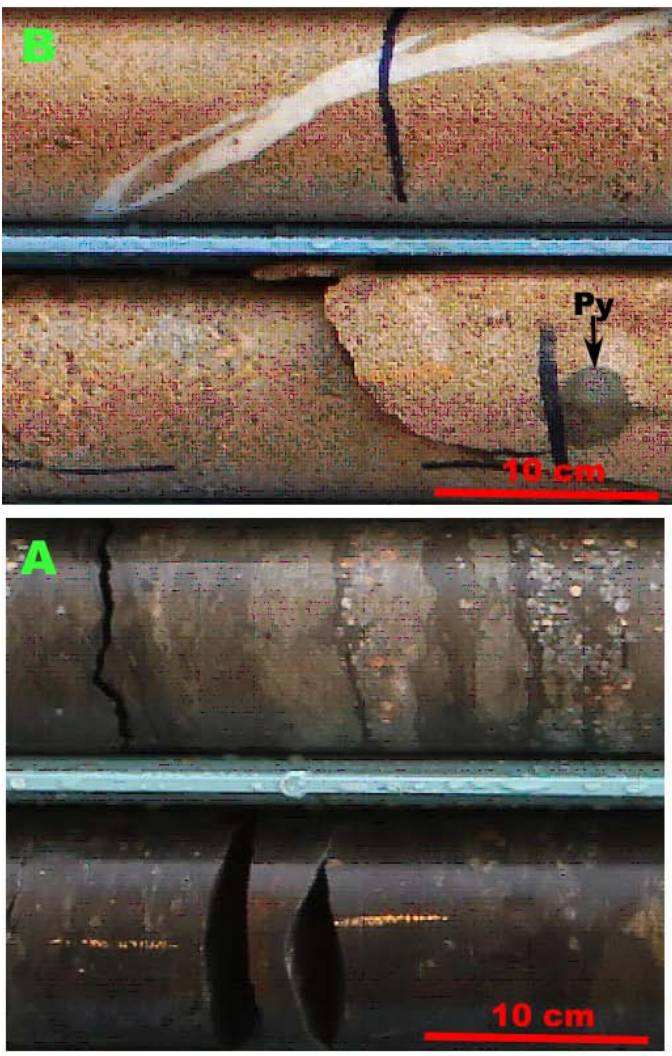
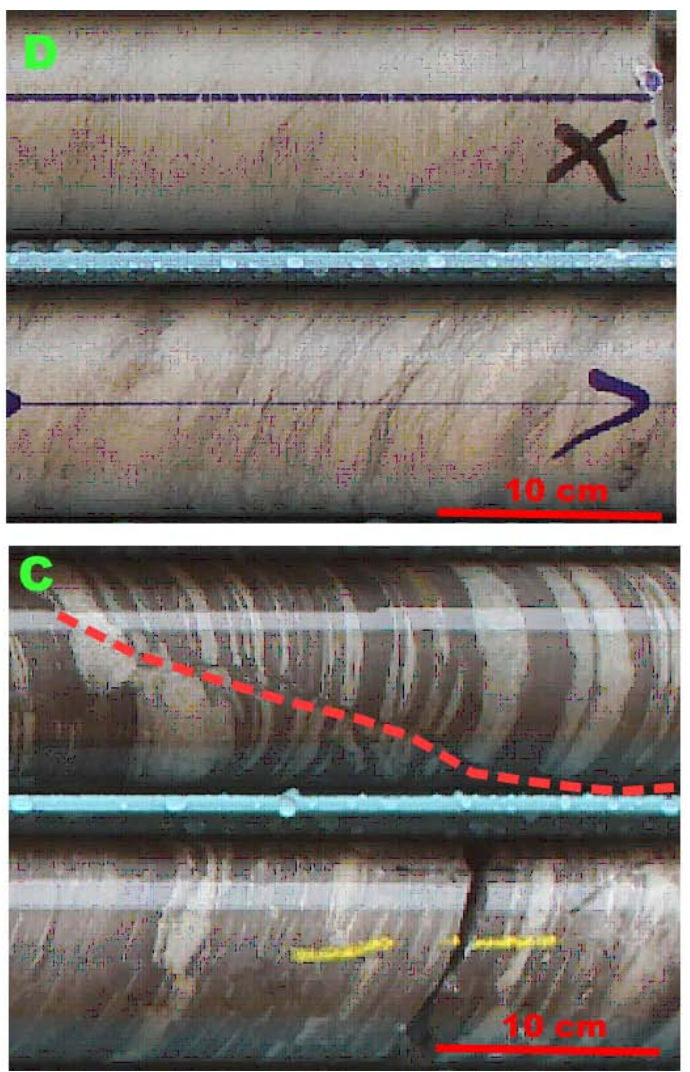

Fig. 8: Core sample characteristics of the Lower Carboniferous sediments ( $A=$ Talak, $B=$ Guezouman, $\mathrm{C}=$ Guezoumanalternance and $\mathrm{D}=$ Tchinozogue formation)
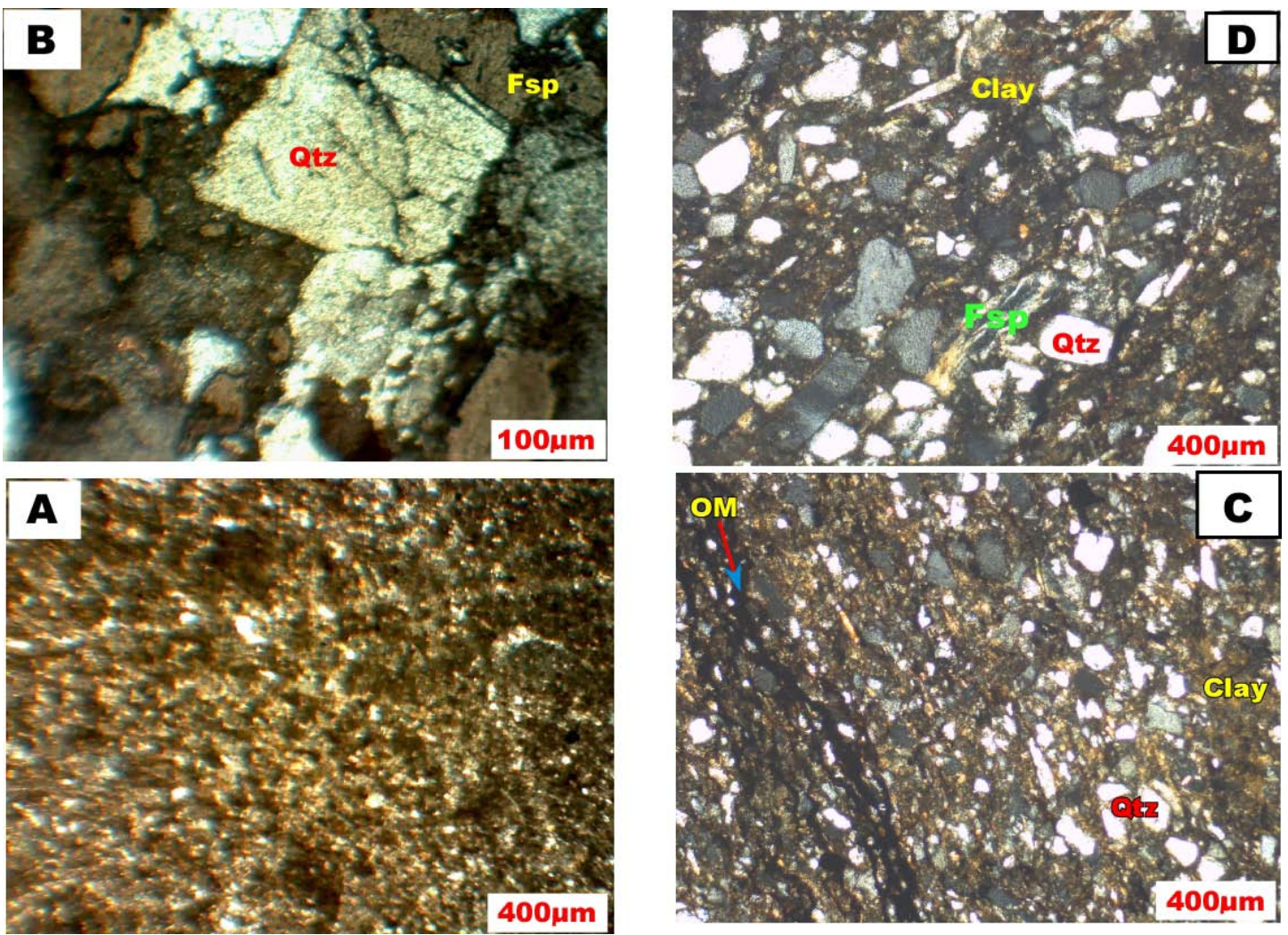

Fig. 9: Thin-section characteristics of the Lower Carboniferous sediments of the DASA graben. $(A=$ Talak, $\mathrm{B}=$ Guezouman, $\mathrm{C}=$ Guezoumanalternance and $\mathrm{D}=$ Tchinozogue formation). 


\section{b. The Upper Carboniferous (Namur to} Westphalian)

They are composed of the following formations (Fig. 10).

a. The fluvio-deltaic Tarat formation, which consists of medium to coarse grained greyish sandstone (Figs. $10 \mathrm{~A} 1$ and A2). The quartz elements have mostly rounded to sub-rounded shapes. The Tarat formation frequently contains organic matter and pyrite.

b. The estuarine to marine Madaouela formation consists of alternating arkosic sandstones and
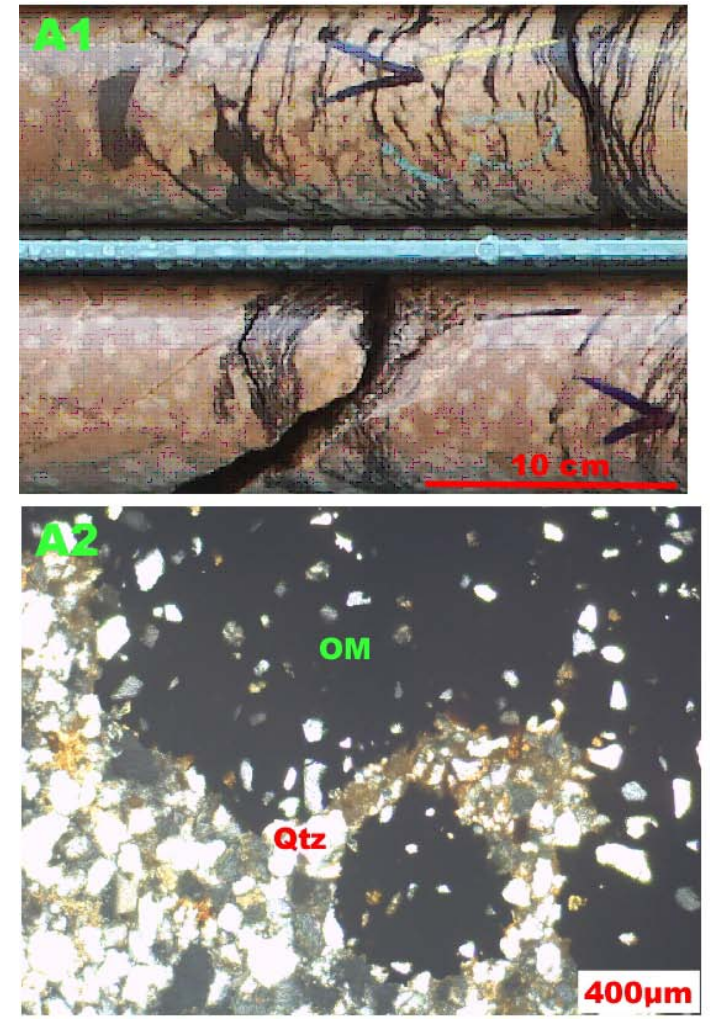

brownish to purplish clay (Fig. 10B1). Two types of lithofacies are distinguished:

$\checkmark$ Coarse-grained sandstones that mostly consist of detrital quartz, feldspar and rock fragments (Fig. 10B2). Calcite and mud are acting as dominant cement with quartz and feldspar.

$\checkmark$ Fine-grained sandstone. This lithofacies consists of fine-grained sandstone with sub-angular to rounded and moderately sorted grains. It's represented by quartz, feldspar and lithic rock fragments. The cement is represented by kaolinite and calcite.
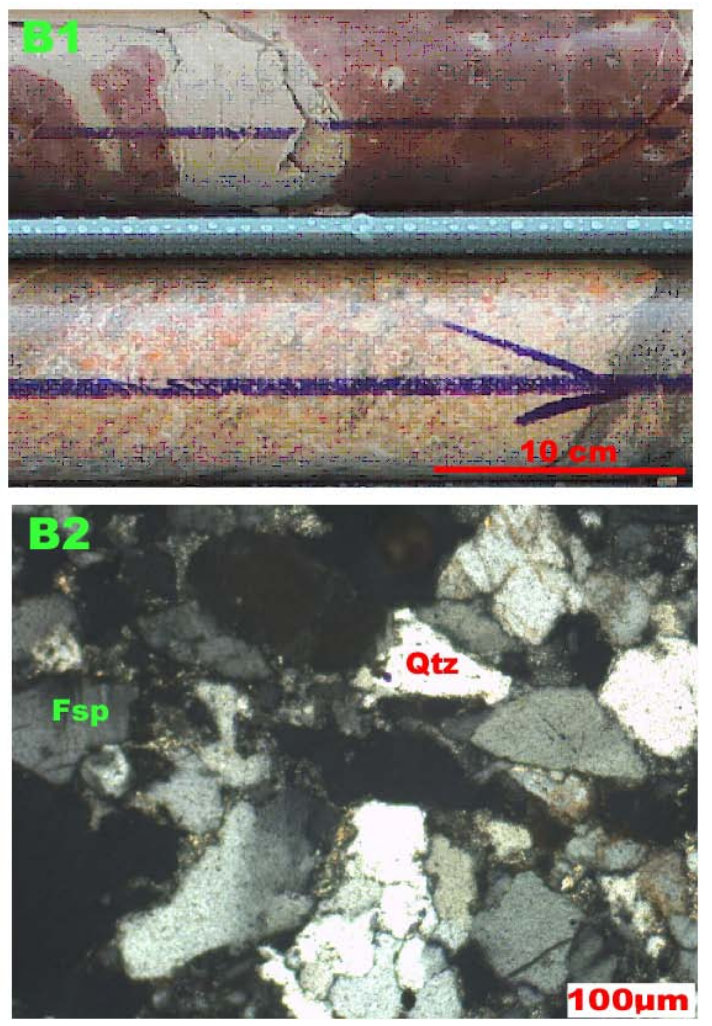

Fig. 10: Core samples and thin-sections characteristics of the Upper Carboniferous ( $A=$ Tarat formation and $\mathrm{B}=$ Madaouela formation)

\section{iv. Permian}

The Permian marks the first appearance of the continental fluvio-lacustrine series in the Tim Mersoï basin. These deposits include intercalated pyroclastic levels which originated from the erosion of the Air Mountains volcanic rocks. The Permian (Fig. 11) is composed of the following formations.

1. Izégouandane formation. This formation is represented by medium to coarse-grained arkosic sandstone (Fig. 11B). It's composed of feldspar and quartz (Fig. 11B) with various rock fragments and analcimolites. Calcite and clay mineral represent the cement between the feldspar and quartz grains.

2. Téjia formation. This formation consists of carbonated mudstone and siltstone with various colors (red, brown, gray). Fine grained sandstones show inter-laminations of silty and muddy layers.
3. Tamamaït formation. It consists of fine-grained sandstones. The quartz grains have a sub-angular to rounded shape. Kaolinite and calcite constitute the pore filling cement.

4. Moradi formation. This is mostly composed of reddish carbonated mudstones (Fig. 11A) and arkosic analcime-rich coarse-grained sandstones, including intercalations of greyish carbonated siltstones.

The major characteristic of the Permian terrain is the reddish color and the abundance of calcitic cement. 

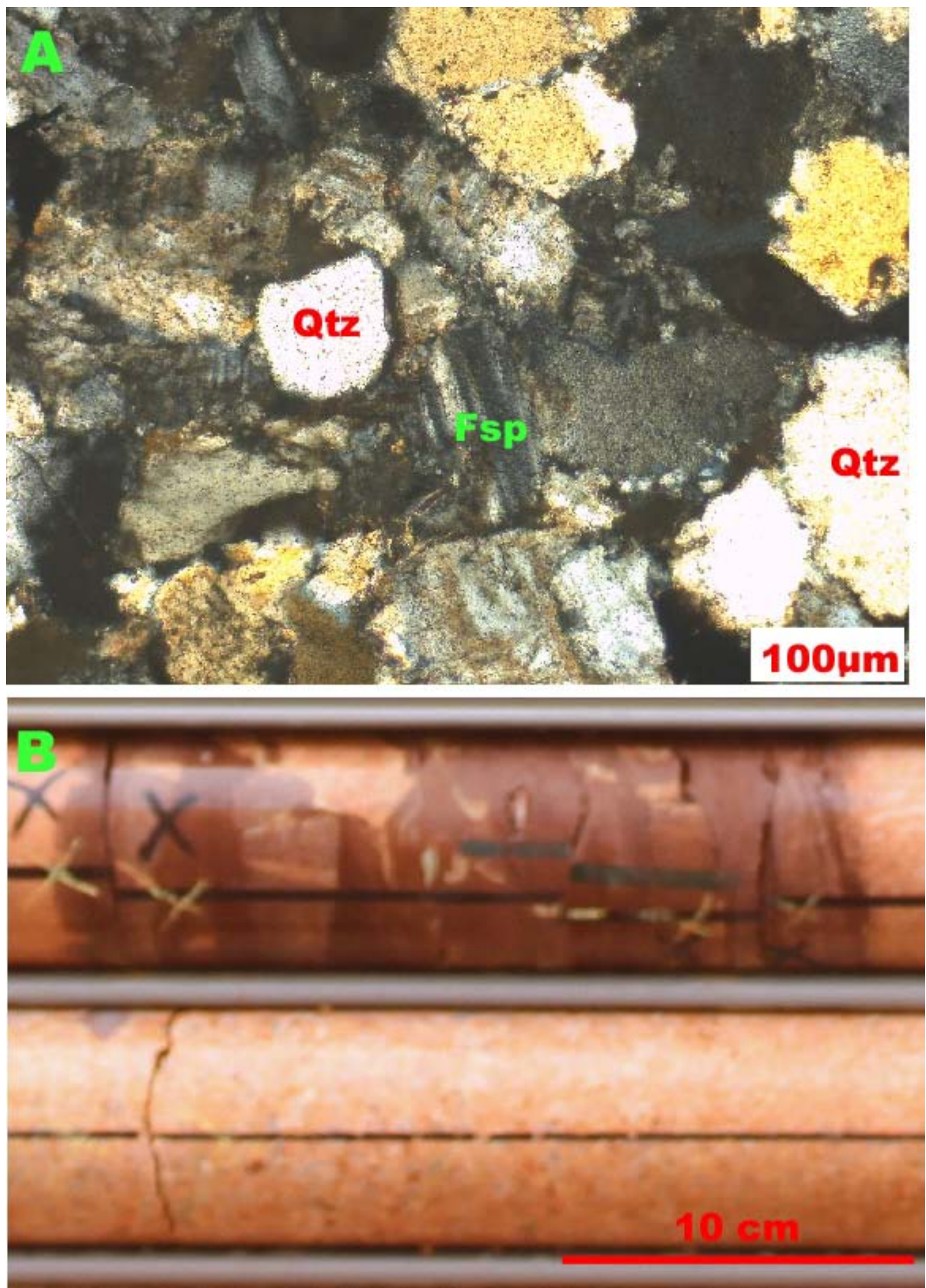

Fig. 11: Core samples and thin-section characteristics of the Permian formation 
v. Triassic to Jurassic

It consists of fluvio-lacustrine terrains (Figs. 12 A1 and A2) with volcanic fractions and are composed essentially of quartz and feldspar of various sizes (Fig. 12 A2). Detrital grains exhibit some time tension gashes and cataclastic features. Analcime is frequently observed (Figs. 12B1 and B2).

\section{iv. Lower Cretaceous}

$\checkmark$ Irhazer formation. It outcrop over a wide area and are mainly made up of reddish continental
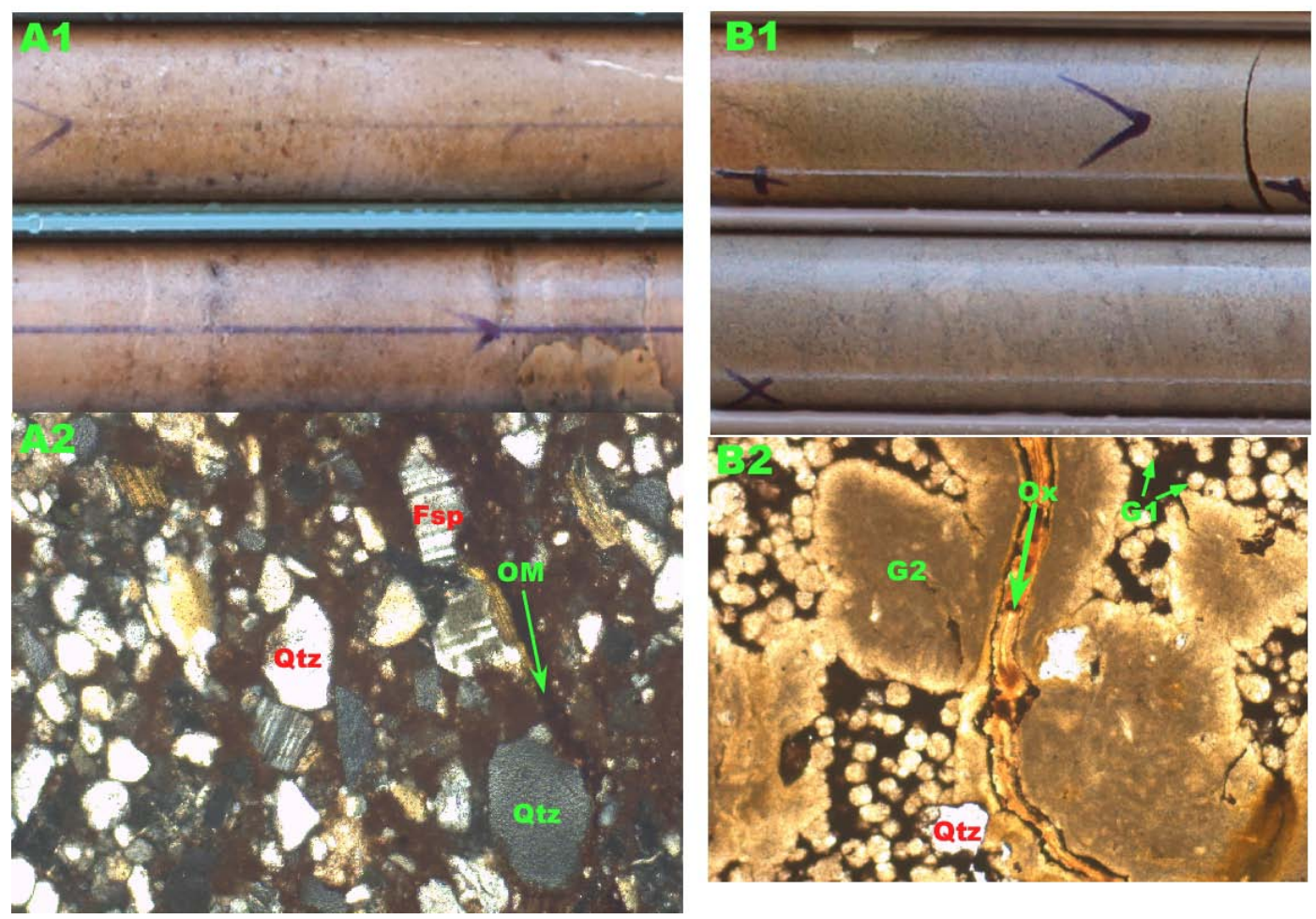

Fig. 12: Core samples and thin-sections characteristics of the Triassic-Jurassic sediments of the DASA graben ( $A=$ Triassic formation and $B=$ Jurassic formation)

\section{Petrographic Features of the Mineralized Formations}

The petrographic features of the mineralized formations of the DASA graben were obtained by using field and thin-section observations.

\section{a) Carboniferous Formations}

A detailed study of the Carboniferous formations indicate that they are highly heterogeneous and texturally immature to slightly mature and sedimentation control of the preliminary porosity and effect the post-transformation. A thin-section study reveals that quartz is the dominant detrital mineral and is mostly monocrystalline with a percentage of $70-95 \%$ (Fig. 13). The feldspar is the second abundant rockforming mineral with a content of $2-25 \%$. The third component are lithic rock fragments that range up to $5 \%$. Distinguished lithofacies are:

- Conglomeratic sandstone claystones and sandstones. They consist from the bottom to top of Irhazer claystones and Tégama sandstones.

$\checkmark$ The Tégama sandstones constitute the last fluvial sandstones deposits before the Upper Cretaceous marine transgression (Irhazer claystones). 


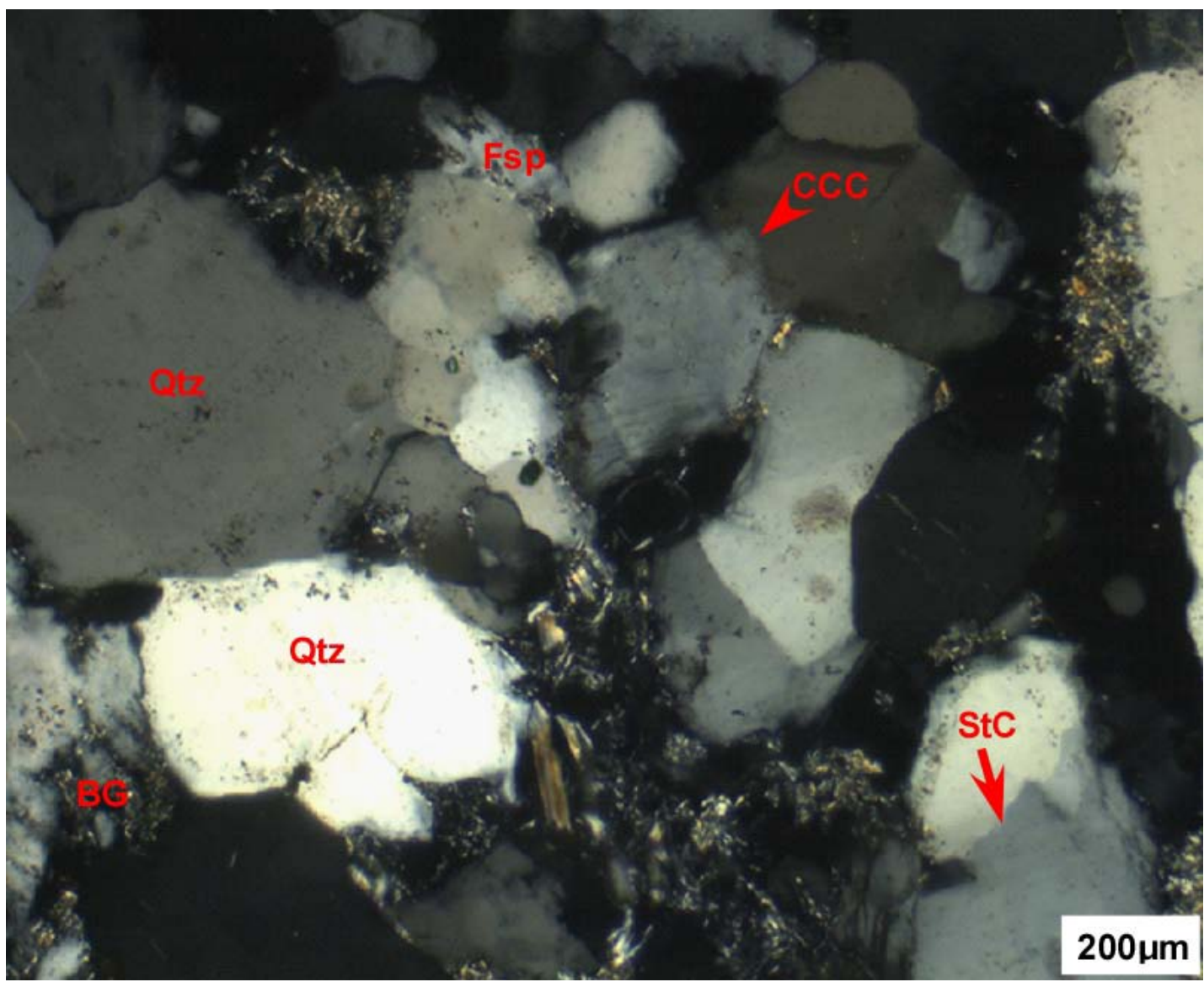

Fig. 13: Thin-section of the Carboniferous mineralized formations showing broken grain (BG), styolithic contact (StC) and Concavo-convex contact (CCC)

b) Triassic Formations

Thin-section analysis of three samples reveals that there are several types of lithofacies. Sedimentary lithofacies consist of:

- Conglomeratic sandstone

- Fine isogranular sandstone

- Medium-grained sandstone with analcimoite

- Siltstone with analcimolites

Field and thin-sections studies show that these lithofacies are moderately sorted with an abundance of detrital quartz and feldspar and rock fragment of analcimolites with clay cement (Fig. 14). Detrital quartz grains are rounded to sub-rounded (Fig. 14). These formations are enriched with analcime and organic matter (Fig. 15). 


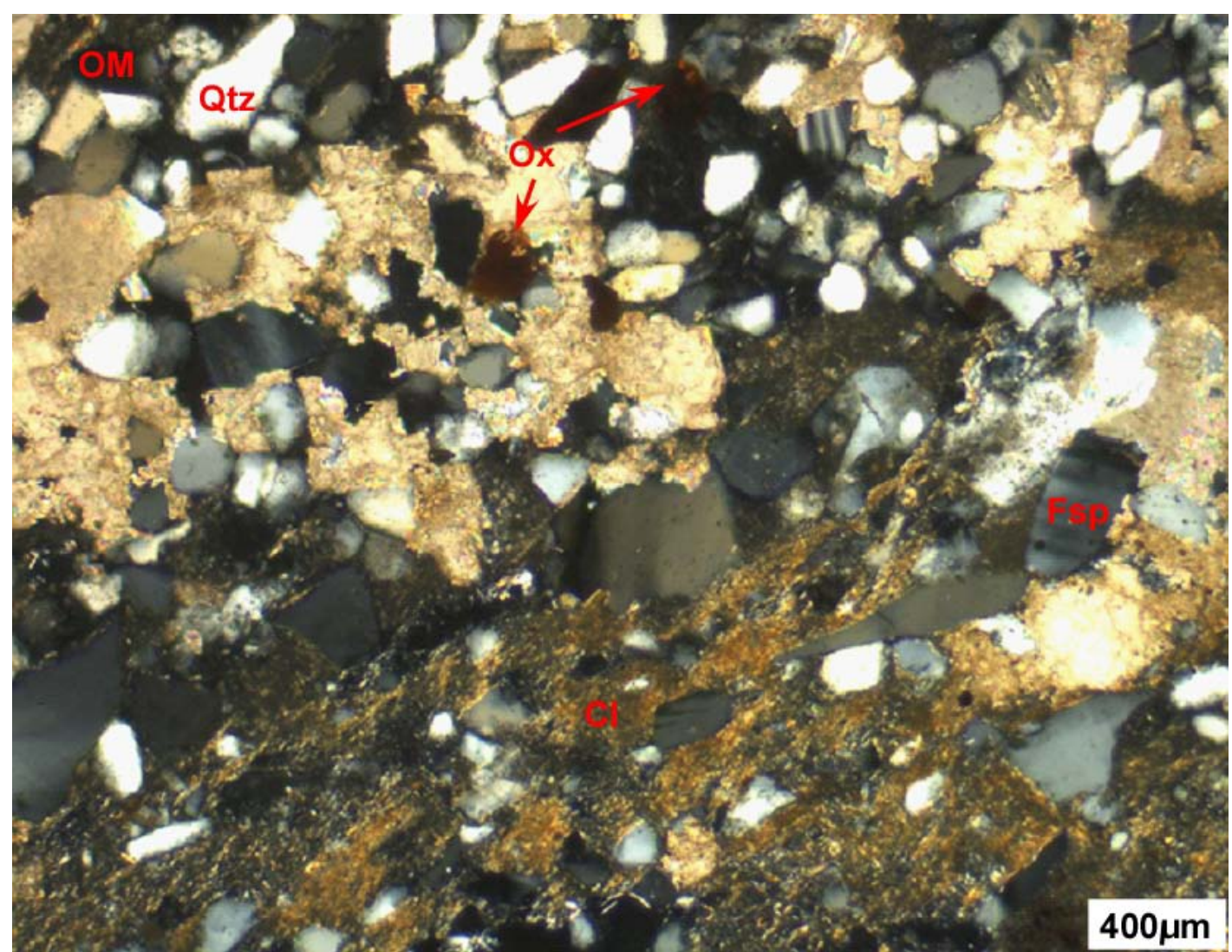

Fig. 14: Thin-section of the Triassicmineralized formation showing organic matter $(\mathrm{OM})$, clay $(\mathrm{Cl})$ and oxides $(\mathrm{Ox})$.

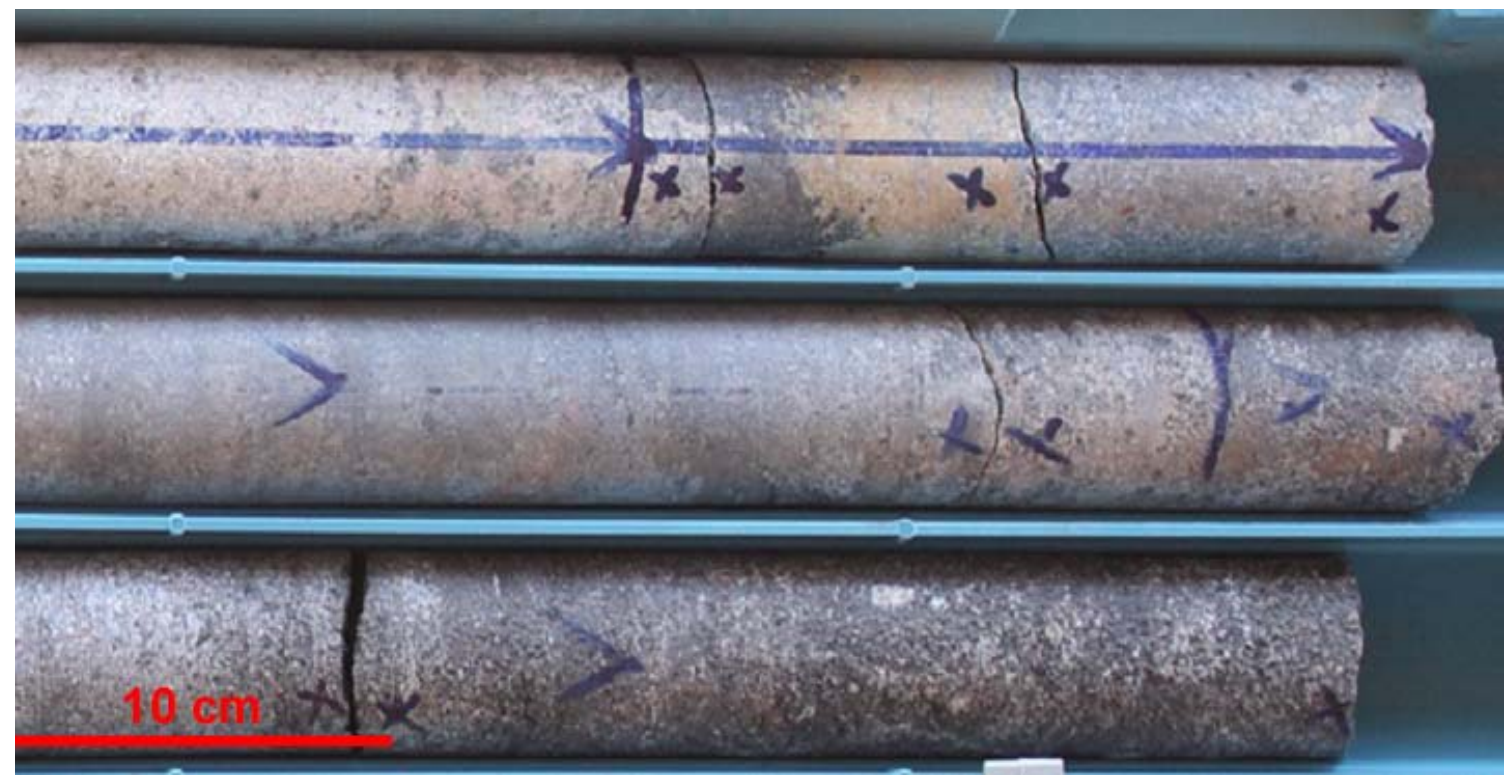

Fig. 15: Organic matter enriched core samples of the Triassic formation

\section{c) Jurassique Formations}

Core samples and thin-sections studies show that Jurassic formations consist of:

- Coarse-grained sandstone

- Medium-grained sandstone

- Siltstone/silty-muddy sandstone with analcimolites.

On the basis of petrographic thin-section and field observations, the sandstone of the Jurassic formation hosting the $U$ mineralization are composed of $76-85 \%$ quartz depending on the amount of analcime, and quartz cement $(5-10 \%)$, feldspar $(5-10 \%)$, clay (2$5 \%)$, oxyhydroxides (2-3\%), and Cu sulfides in minor amounts (Fig. 16). Some clay and calcite is replaced by iron-oxides acting as a cement in the studied samples (Fig. 16). 


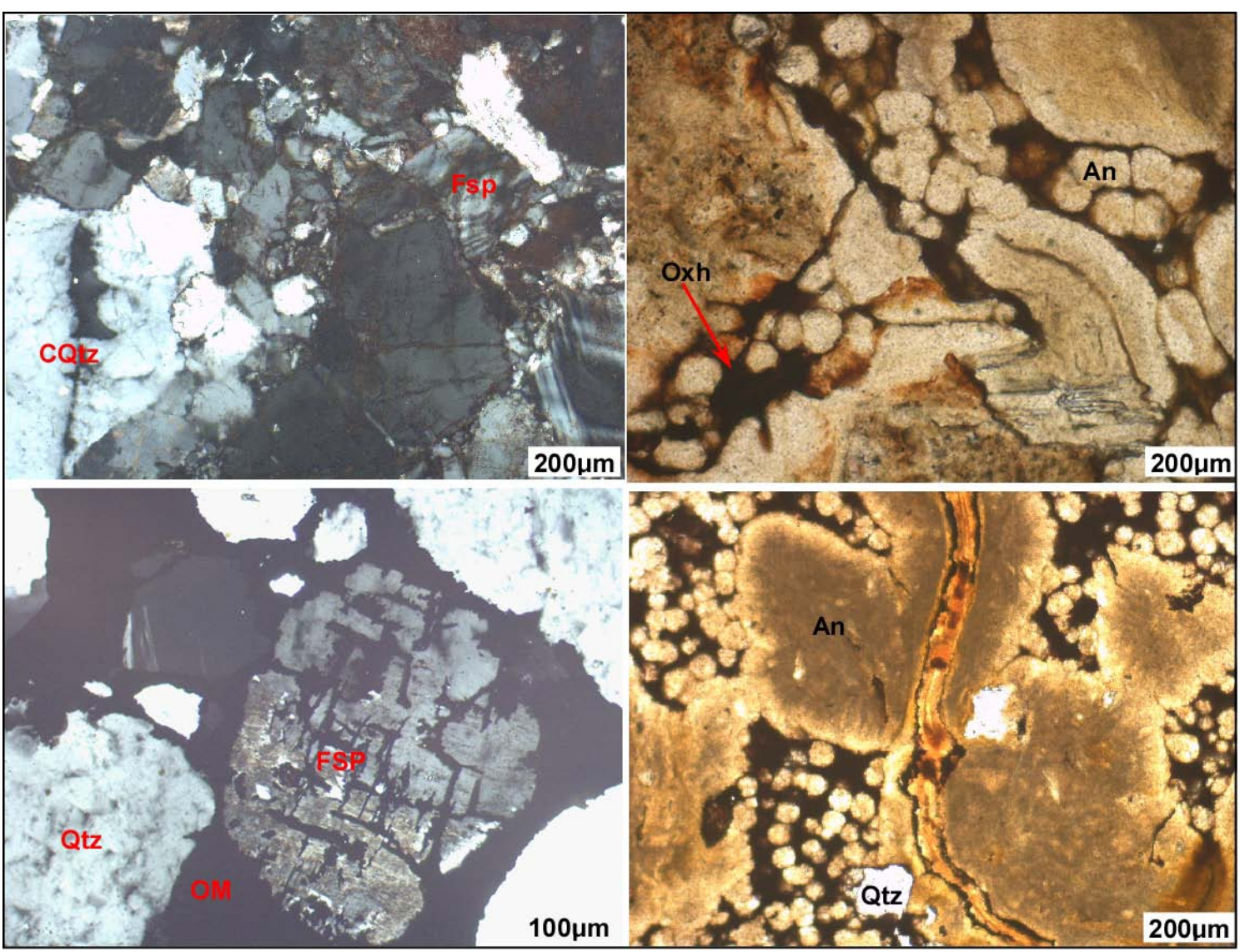

Fig. 16: Different variants of thin-sections of Jurassic series showing analcime (An), quartz (Qtz), cataclased quartz (CQtz), feldspar (Fsp), organic matter (OM) and oxyhydroxides

\section{Vi. Tectonics and Sedimentation}

To better understand the DASA graben structures, synthetic cross-section (location in Fig. 5) from well log correlation were constructed, (Fig. 17). This approach allowed examining the lateral and vertical succession of the different facies and the relationships between tectonics and sedimentation. The geological cross section obtained shows, that in the axial zone of the DASA graben, the maximum thickness of the sediments is about $805 \mathrm{~m}$ (according to the borehole data), for a sedimentation period of $246 \mathrm{Ma}$ (according to the lithostratigraphic column). This implies a lower subsidence of about $3.22 \mathrm{~m} / \mathrm{Ma}$ (Figs. 3 and 17) compared to that of the Tim Mersoï basin whose subsidence is on average $5.3 \mathrm{~m} / \mathrm{Ma}$ (Figs. 3 and 17). Most sedimentary series of the DASA graben exhibit variations in thickness on both sides of the border faults (Figs. 3 and 17).

According to Sani et al (2020) the sedimentary infilling of the DASA graben is typified by two periods of subsidence.

\section{a) First Period of Subsidence}

This period was characterized by a low subsidence rate $(3.75 \mathrm{~m} / \mathrm{Ma}$ on average), and extends from the Carboniferous to the Permian. The Permian series are particularly marked by a strong reduction in thickness in the axial zone of the graben $(30 \mathrm{~m})$ compared to the edge zones (188-215 m) (Fig. 17) (Sani et al (2020)).

\section{b) Second Period of Subsidence}

The second period was marked by a strong subsidence rate $(4.11 \mathrm{~m} / \mathrm{Ma})$ lasting from the Triassic to the lower Cretaceous (Fig. 17). The strongest subsidence rate occurred during the Lower Cretaceous in the axial zone $(6.52 \mathrm{~m} / \mathrm{Ma})$ while in the border zones the subsidence rate was very low (1.17 to $1.65 \mathrm{~m} / \mathrm{Ma})$ (Fig. 17) (Sani et al (2020)).

The subsidence inversions occurring between the axial zone of the DASA graben and the edge zones reflect a morphological inversion related to a change in the tectonic regime.

During the first period, from the Carboniferous to the Permian, the axial zone of the DASA graben was affected by an uplift stage. During the second subsidence the highest thicknesses of the sediments are observed in the axial zone of the graben whereas the thicknesses are lower on the border zones. The DASA sector was affected by a rifting stage. 


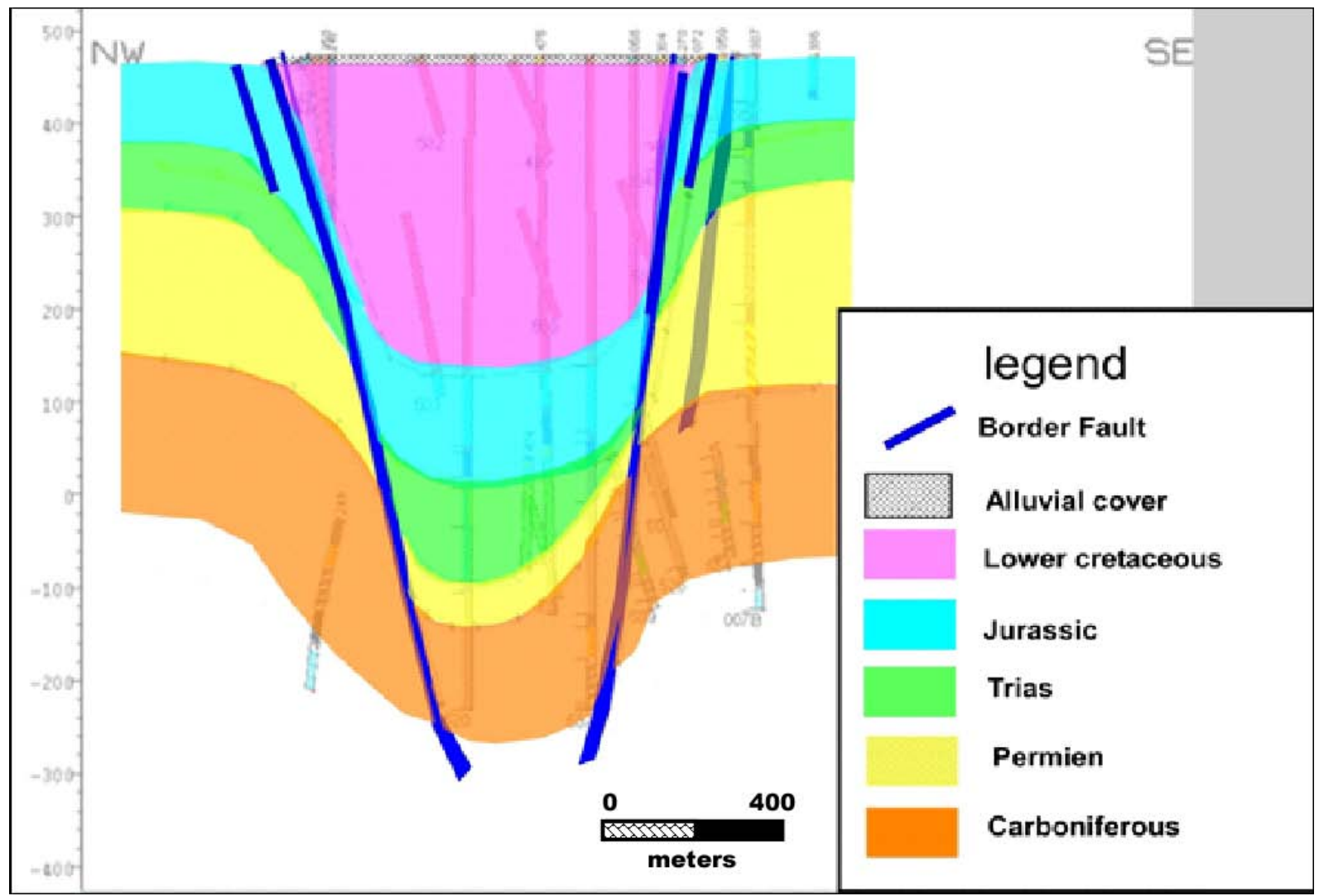

Fig. 17: Geological section of the DASA graben made from survey data

\section{Vil. Mineralogy and Uranium}

\section{Distribution in the Dasa Graben}

Results used herewith are of the Jurassic formation in the Tchirezrine 2 near surface mineralization. The description of the mineralization is based on grade, depth and association of $U$ with other elements. The uniqueness of uranium mineralizations in the DASA graben is :

$\checkmark$ All formations known to contain uranium in the Tim Mersoi basin are present at DASA.

$\checkmark$ The grades are higher than in nearly all other uranium deposits in the Tim Mersoi basin (>1\%).

The sandstones hosting the DASA uranium mineralization in the Carboniferous are composed of quartz (70-80\%), feldspar (10-20\%), clay (5-10\%), oxyhydroxides (3-5\%), organic matter and pyrite while in the Triassic and Jurassic formations the sandstones are composed of quartz (66-75\%), feldspar (7-15\%), analcime (7-10\%), clay(5-7\%) and oxyhydroxides (2-6\%). In the DASA graben, the highest concentrations of uranium mineralization are observed in its southeastern part (Fig. 18), which corresponds to the most faulted area. 


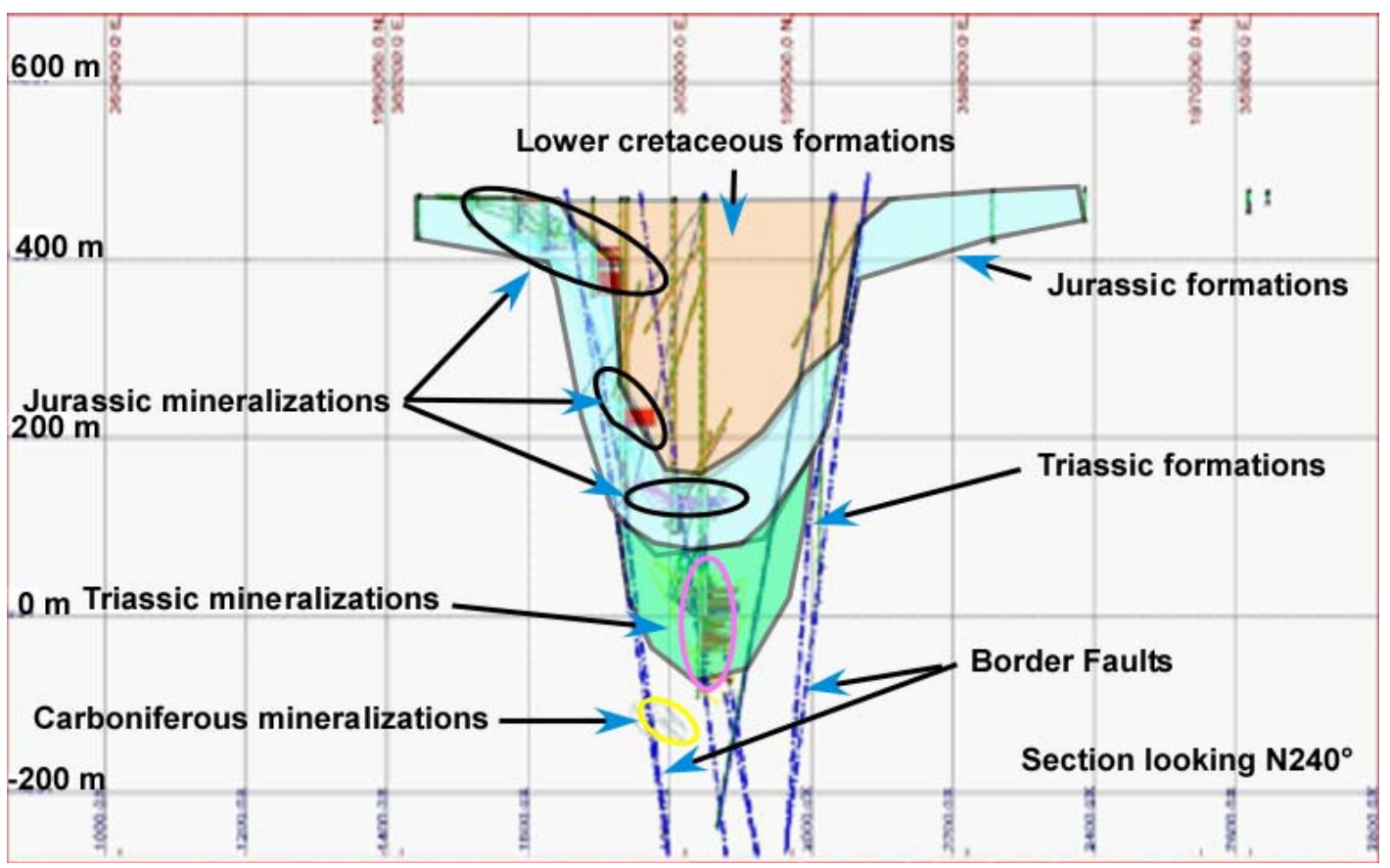

Fig. 18: Uranium distribution in the DASA graben

a) Mineralization In The Carboniferous

The uranium ore in the DASA graben was discovered in Carboniferous formations (Guézouman, Tarat and Madaouéla). The mineralization is hosted in organic matter (Figs. 19 a and b) and /or pyrite rich sandstones. The mineralized zone is $34 \mathrm{~m}$ to $82 \mathrm{~m}$ thick and $\mathrm{U}_{3} \mathrm{O}_{8}$ grades range from 0.31 to $0.4 \%$ with $1.5 \%$ $\mathrm{U}_{3} \mathrm{O}_{8}$ as the maximum grade (Table 1). b) Mineralization In The Triassic

In the Triassic formations uranium mineralization is hosted in organic matter and/or pyrite rich sandstones and in analcimerich sandstones associated with fracture infilling with calcite (Figs. $19 \mathrm{c}$ and d). The thickness of the Triassic mineralization is shown in Table 1. It may reach continuous from 24 to $131 \mathrm{~m}$ in thickness with grades up to $17.5 \% . \cup_{3} \mathrm{O}_{8}$.

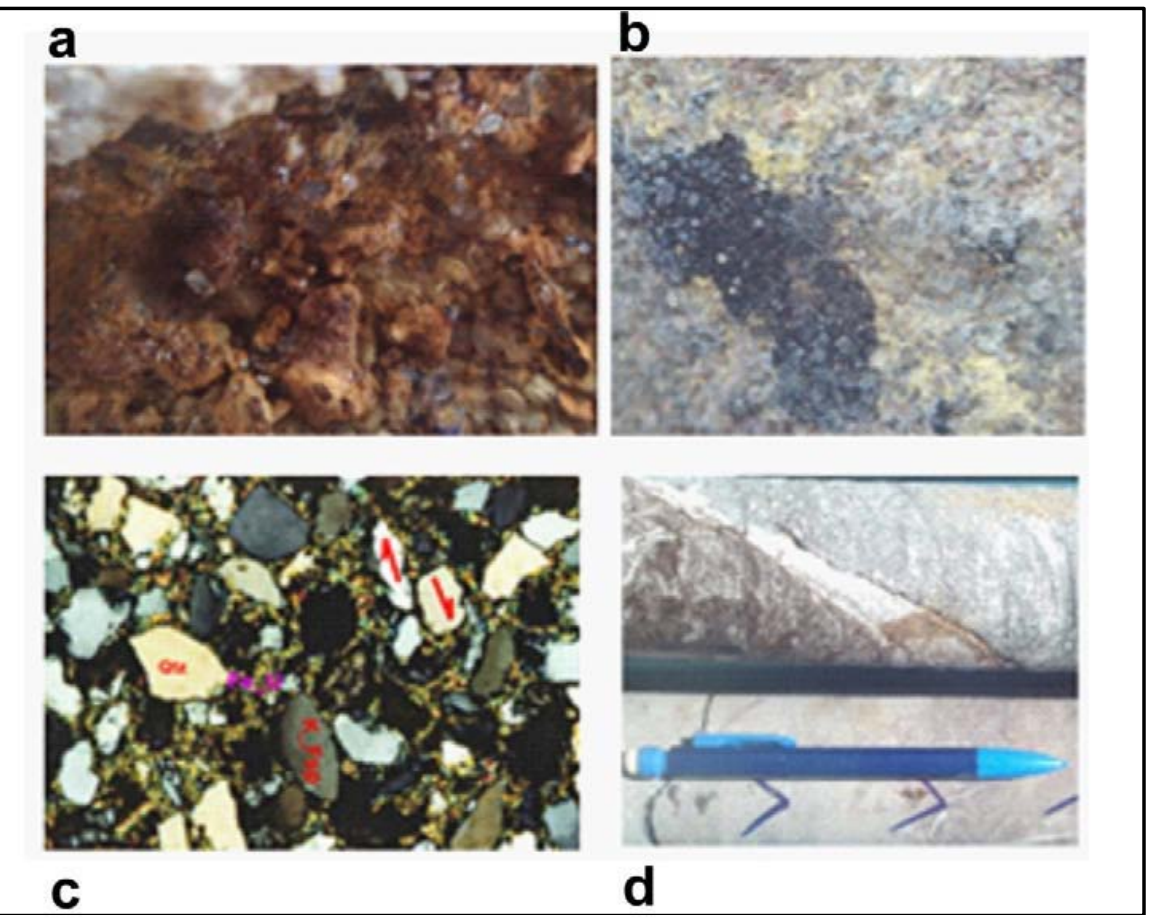

Fig. 19: DASA graben core samples. (a) Oxidized sandstone, (b and c) occurrence of uranium associated with organic matter in DASA sandstone (Carbon or Triassic or Jurassic??), (d) micro fault infilling with calcite 


\section{c) Mineralization In The Jurassic}

The Jurassic mineralization is sub-surface (5-15 $\mathrm{m})$ on the flanks of the graben, while in the axial zone, the mineralization can reach to a depth of $500 \mathrm{~m}$. It should be noted that most of the Jurassic mineralisation is found in the southern zone of the graben (with thicknesses varying between 20 and $34 \mathrm{~m}$ ). The grade of this mineralization varies from 0.25 to $0.55 \% \mathrm{U}_{3} \mathrm{O}_{8}$ with $5.08 \% \cup_{3} \mathrm{O}_{8}$ as the maximum grade (Table 1). The Jurassic mineralization is mainly hosted within the Tchirezrine 2 sandstones, particularly in the coarsergrained micro-conglomeratic facies of greyish-greenish colour containing frequent sulphides, organic matter and analcime (Figs. 20 and 21). The characteristics of this mineralizations is:

$>$ The mineralization is usually hosted in bottom sets with associated organic matter fragment, pyrite/hematite and analcime.

$>$ The mineralization is controlled by tectonics: uranium mineralization occurs within cataclastic structures and breccia attesting to uranium enrichment related to fluids circulation.
The grades are very high for a sedimentary deposit and are rarely found anywhere else in the world/ Thin section work and petrographic studies on the DASA samples has revealed that the main uranium host rocks are oxidized and analcimolitic sandstones. The main component is angular quartz, some plagioclase and lesser orthoclase. They are cemented by goethite, amorphous iron-hydroxides and various secondary uranium-rich minerals (Fig. 22)

The mineralogical studies of the Tchirezrine 2 show that the composition of the uranium minerals is variable. The analyses performed on the core samples yielded six types of uranium minerals such as: Carnotite; Uranophane; U-rich titanite (possibly rutile); Coffinite; Torbernite; Autunite, U-Ti mineral (possibly brannerite) and $\mathrm{U}-\mathrm{Si}$ (possibly coffinite) are the main uranium mineral in all samples. The uranium occurrence is complex and observed as uranium remobilisation is present in micro-fractures, discontinuous rims and finegrained cryptocrystalline inclusions. Trace amounts of uranium minerals are associated with carbonates.

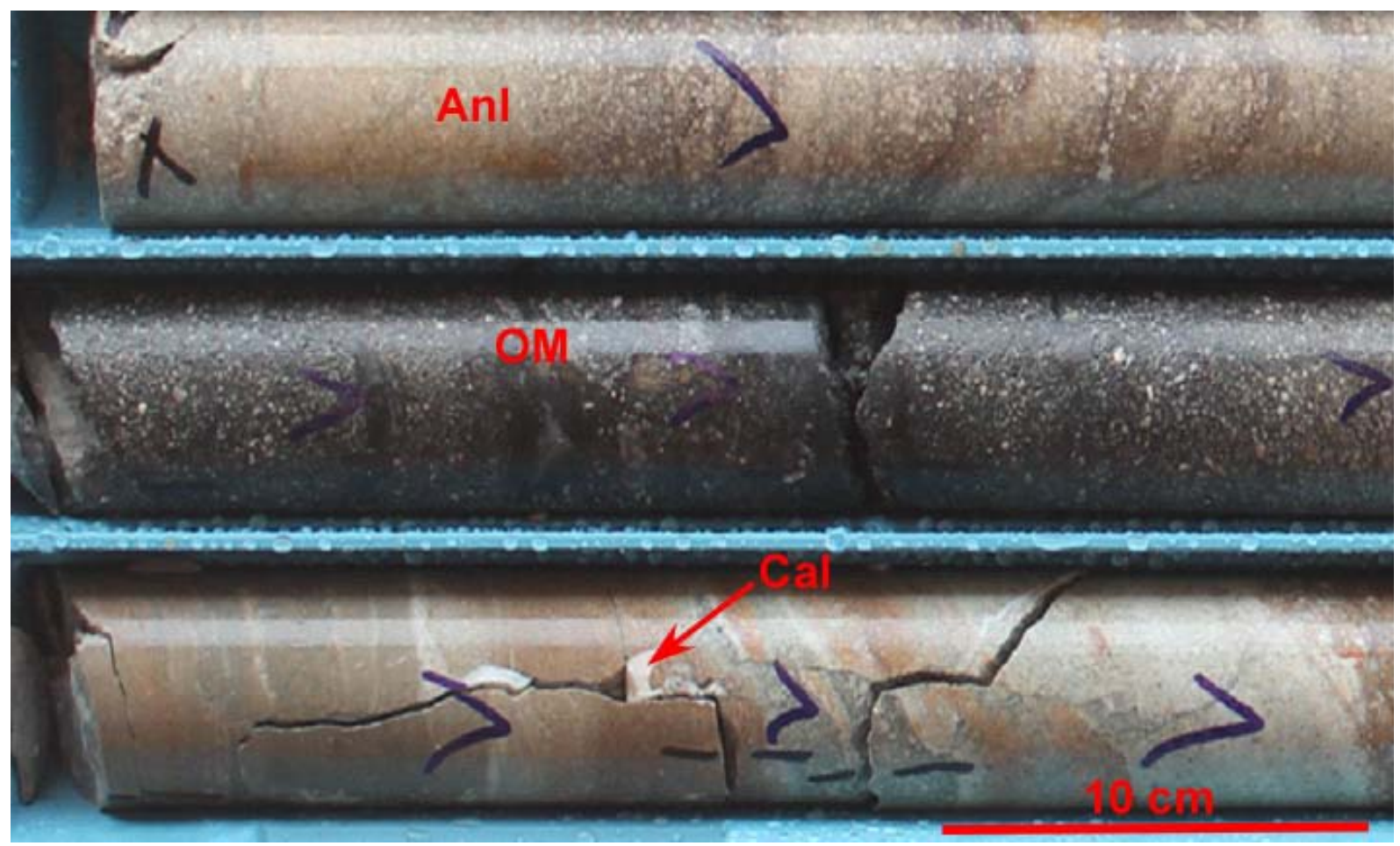

Fig. 20: Triassic formation core sample enriched in organic matter and analcime 

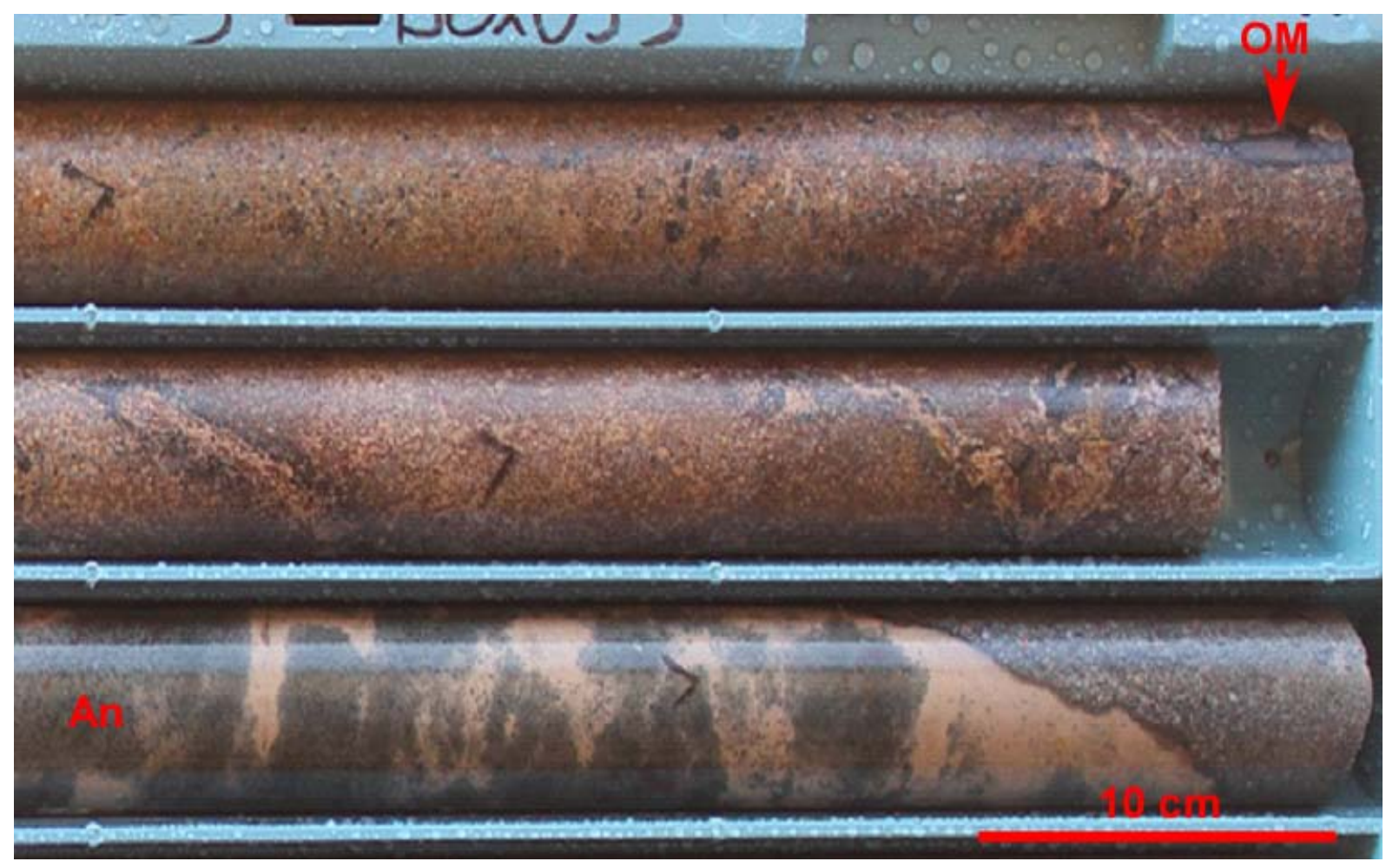

Fig. 21: Jurassic formation core sample enriched in organic matter, analcime and oxyhydroxides 


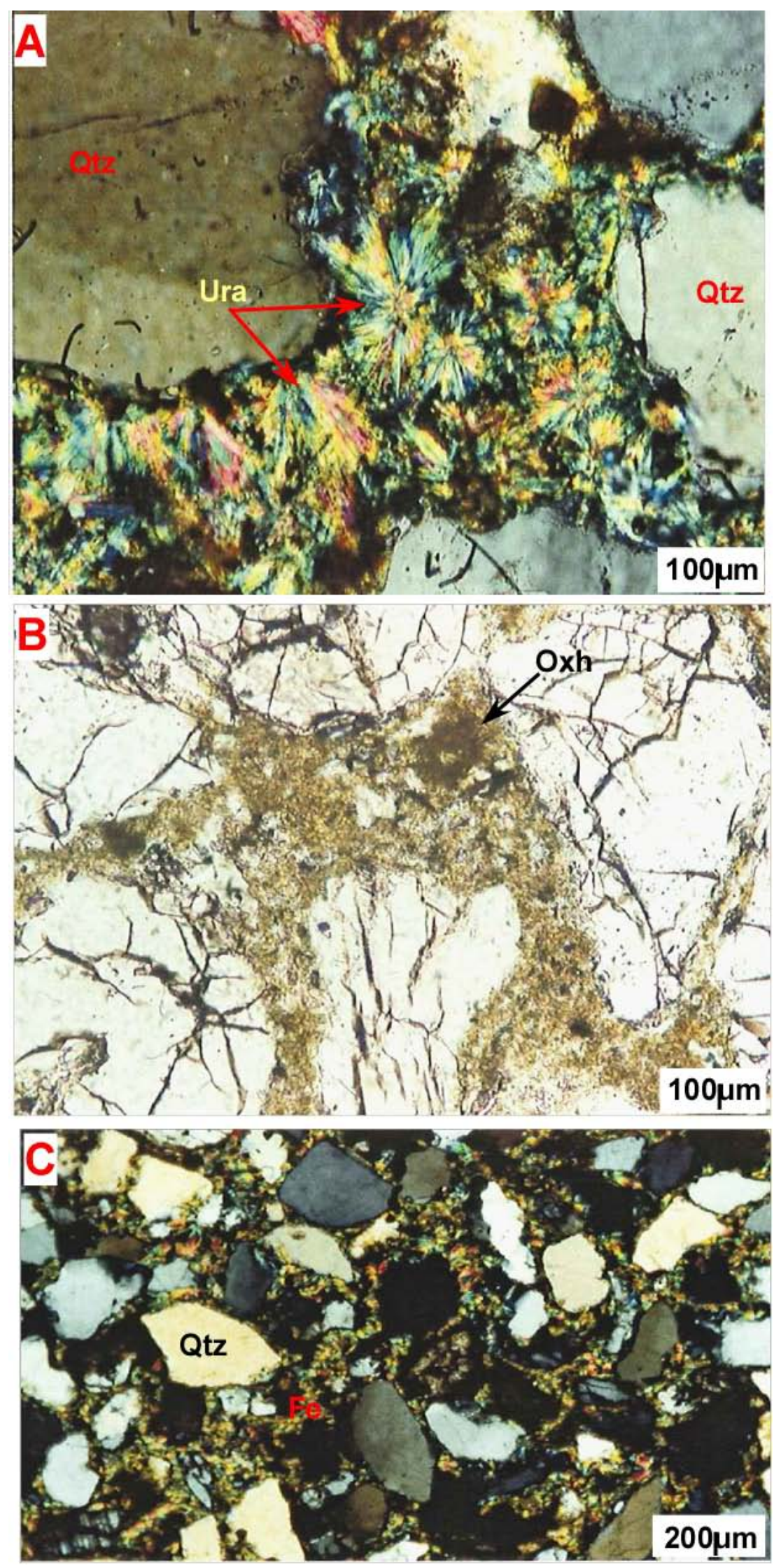

Fig. 22: Thin-sections of the Jurassic formation showing: $A=$ radiant uranophane rosettes partially replacing quartz, $\mathrm{B}=$ radiant uranophane rosettes partially replacing quartz, and $\mathrm{C}=$ angular quartz clasts in an iron-coloured uranophane matrix 


\section{Vili. Microtectonic Analysis}

In the DASA graben, the sedimentary deposits are affected by normal microfaults (syn and post sedimentary). The latter locally display micro horst and meso-graben structures (Fig. 23A). Figure 23C (a) shows a synsedimentary microfault affecting the Carboniferous deposits while Figure 23C (b) corresponds to a synsedimentary microfaults affecting the Jurassic deposits. Shown in Figure 23B is a post sedimentary microfault affecting the Jurassic deposits.

$\vec{\delta} \quad$ The syn-deposition microfaults observed in the DASA graben are generally normal, but may rarely show reverse faults. When exposed, these types of microfaults are recognized by the following characters:

$>$ The patina of the microfaults plane has the same color as the sediment (Fig. 23B);

$>$ The striaes are generally curved (Fig. 24);

$>$ The sedimentary material is not cataclazed;
Jurassic deposits outcropping along the DASA graben are also affected by brittle deformations, linked to late replay of border faults. These late post-deposition microfaults are sometimes characterized by cataclastic zones or by deformation corridors meters in thickness, associated with syncinematic recrystallizations of silica. Microtectonic analysis has allowed to highlight tectoglyphs which, by their characteristics, could be linked to post-deposition deformations. It's about :

$>$ Abrasion or cataclase figures with scales, tear-off lunules (Fig. 24, 25);

$>$ Syncinematic recrystallizations of silica.

In addition to these tectoglyphs, at the level of the DASA graben, post-deposition microfaults are characterized by corridors of millimeter deformations associated with syncinematic recrystallizations of silica and tension fentes (Figs. 26, 27, 28).

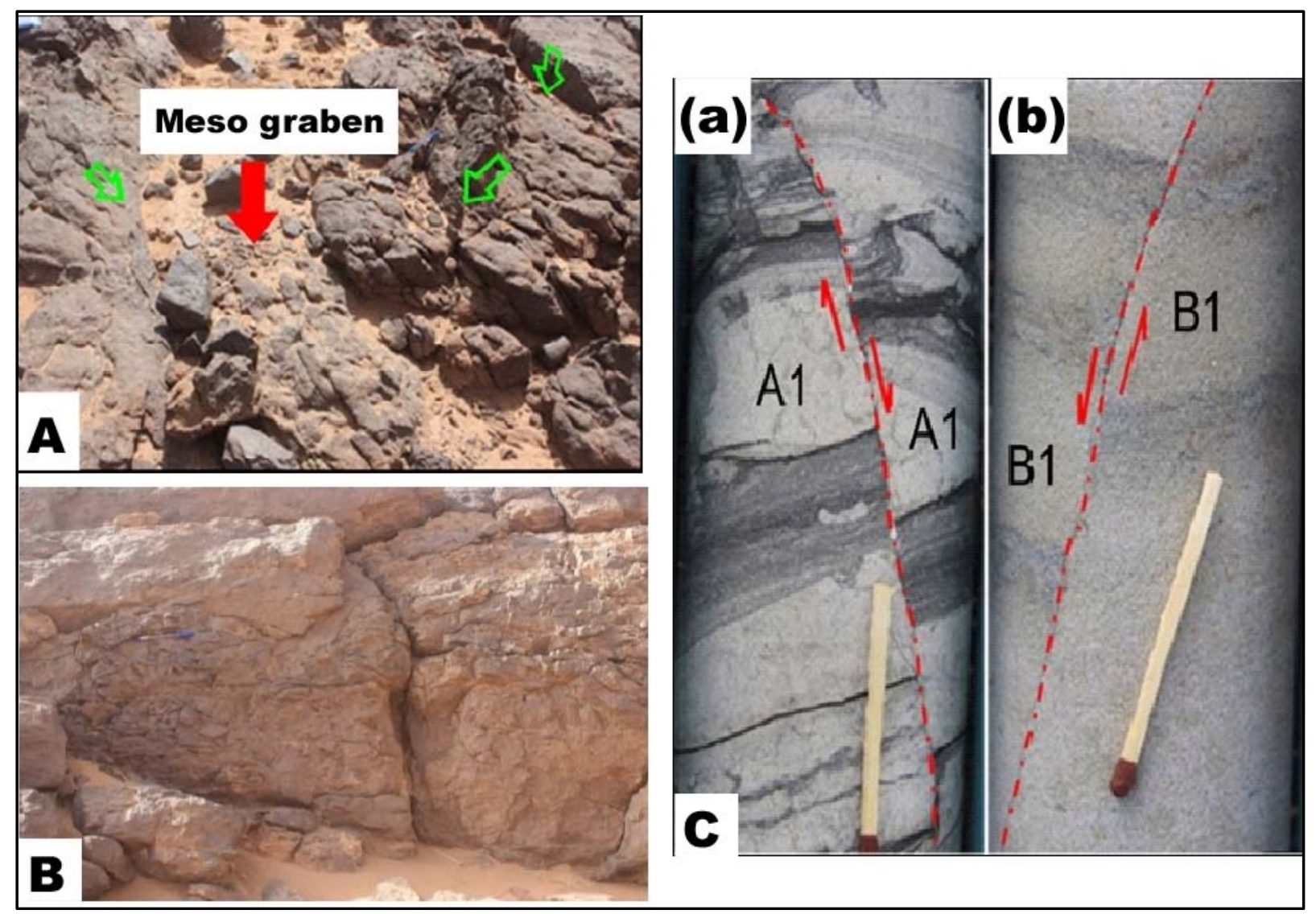

Fig. 23: Microfaults in the DASA graben. A-meso graben, B-cataclazed area in DASA and C-synsedimentationmicrofault on the DASA core. Two criteria are used to distinguish the synsedimentary tectonics. These are, on the one hand levels thickness variations on both side of the microfault and, on the other hand lateral facies variations ((a): in the Carboniferous Tarat formation and (b): in the Jurassic Tchirezrine 2 formation) 


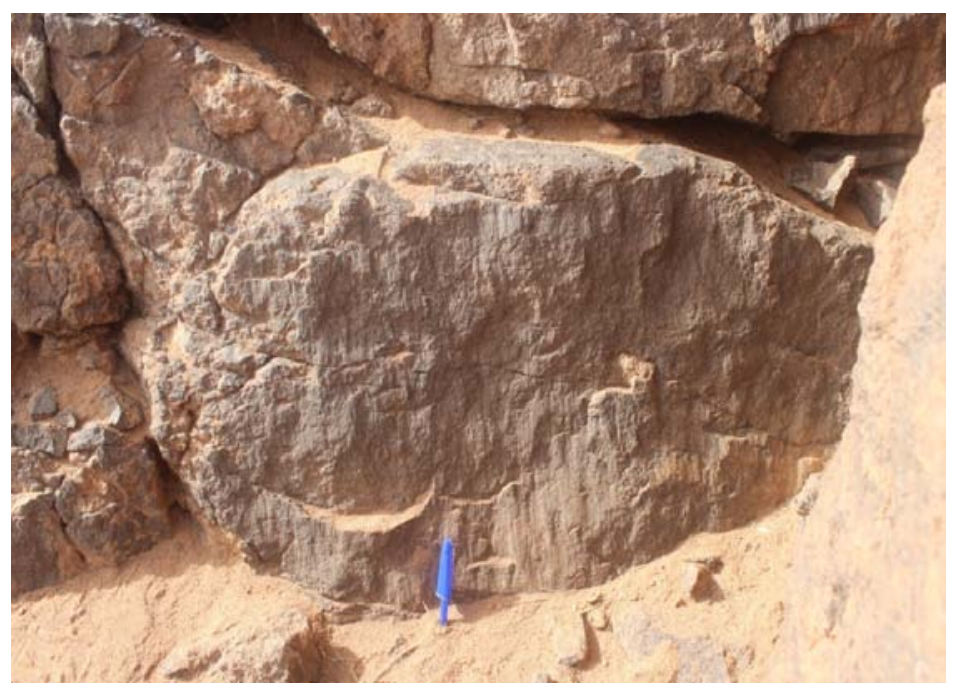

Fig. 24: Microfault Plan oriented N70 E, with more or less fluted striations

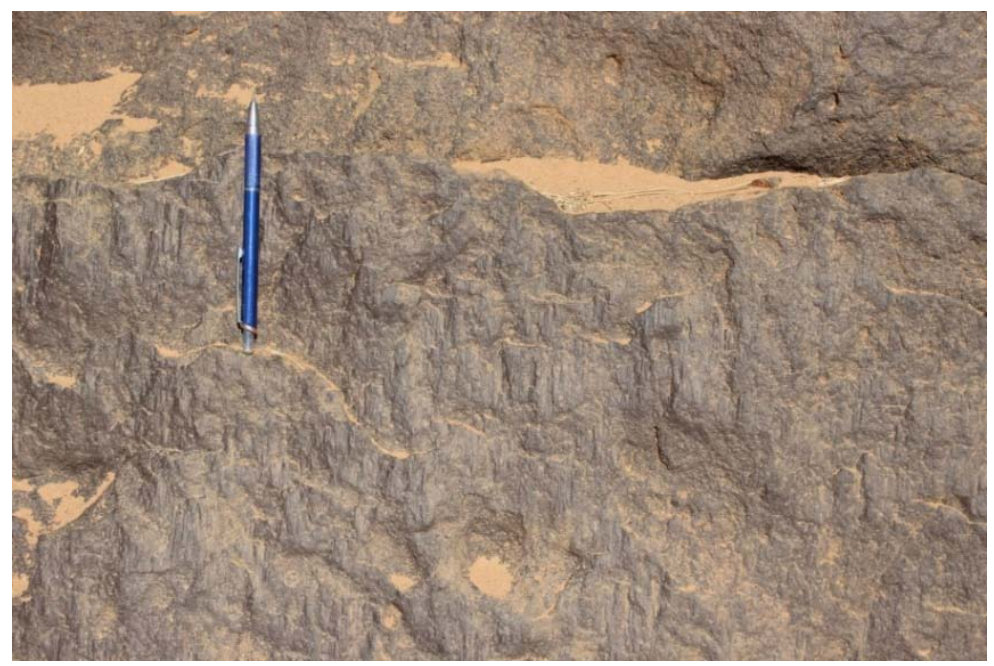

Fig. 25: Normal micro fault plane $\mathrm{N} 70^{\circ}$. The first generation of vertical striation (pitch $\sim 90^{\circ}$ ) is intersected by secondary fractures planes in irregular striations oblique to horizontal. 

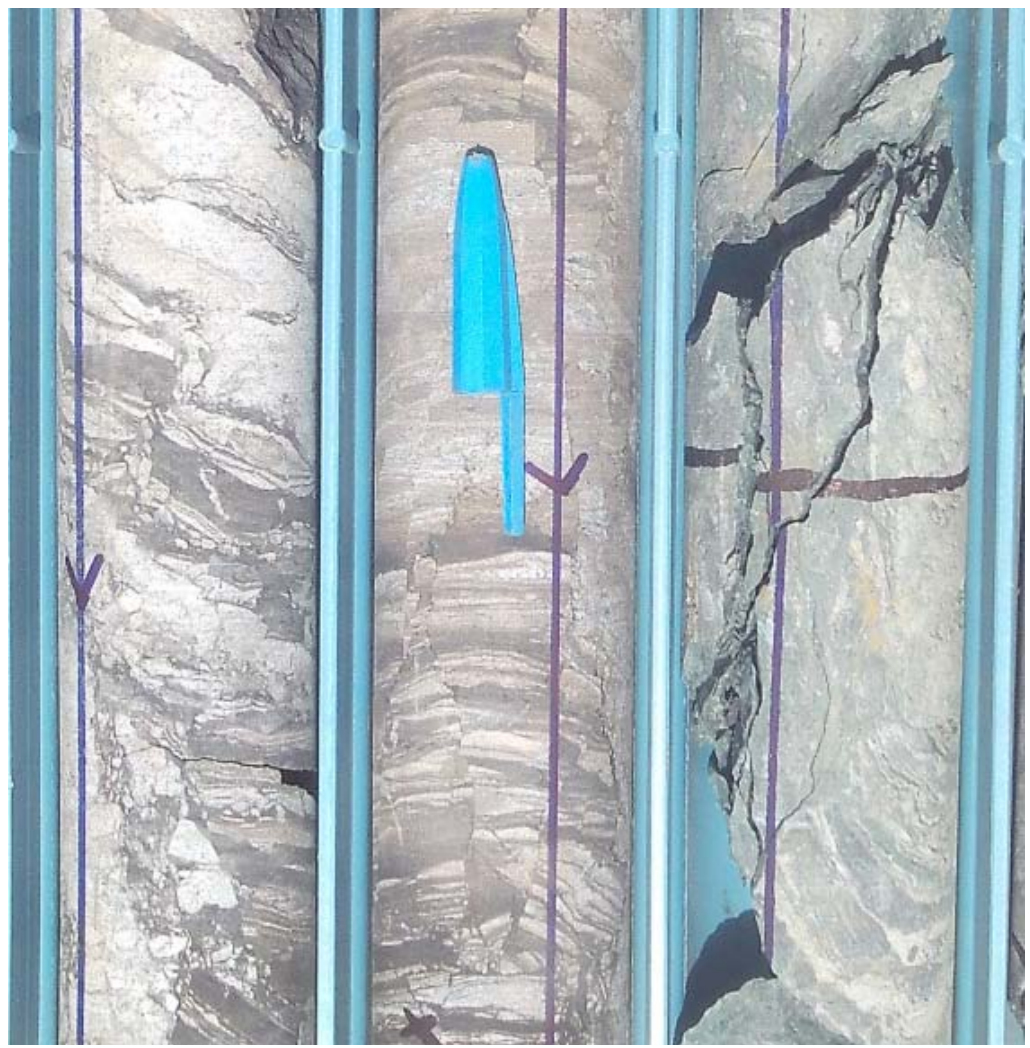

Fig. 26: Core sample from the Carboniferous series showing a post-deposition micro-deformation. The sediment is cataclazed

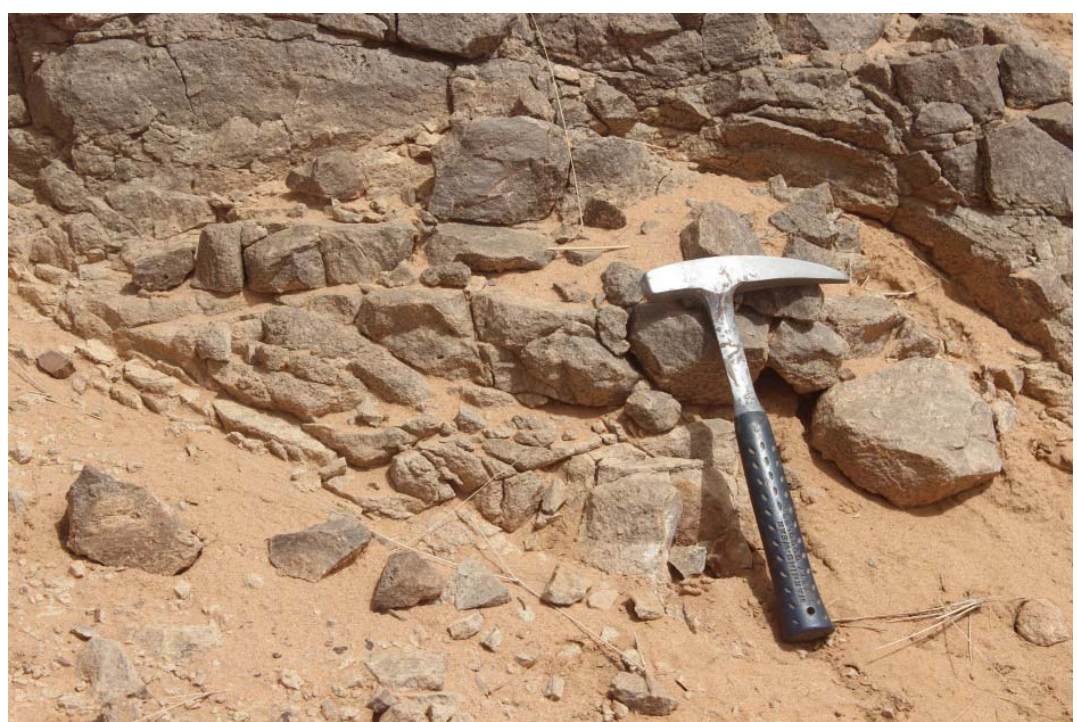

Fig. 27: Thick fault zone, the rock is cataclazed and brecciated over a thickness of about $3 \mathrm{~m}$ 


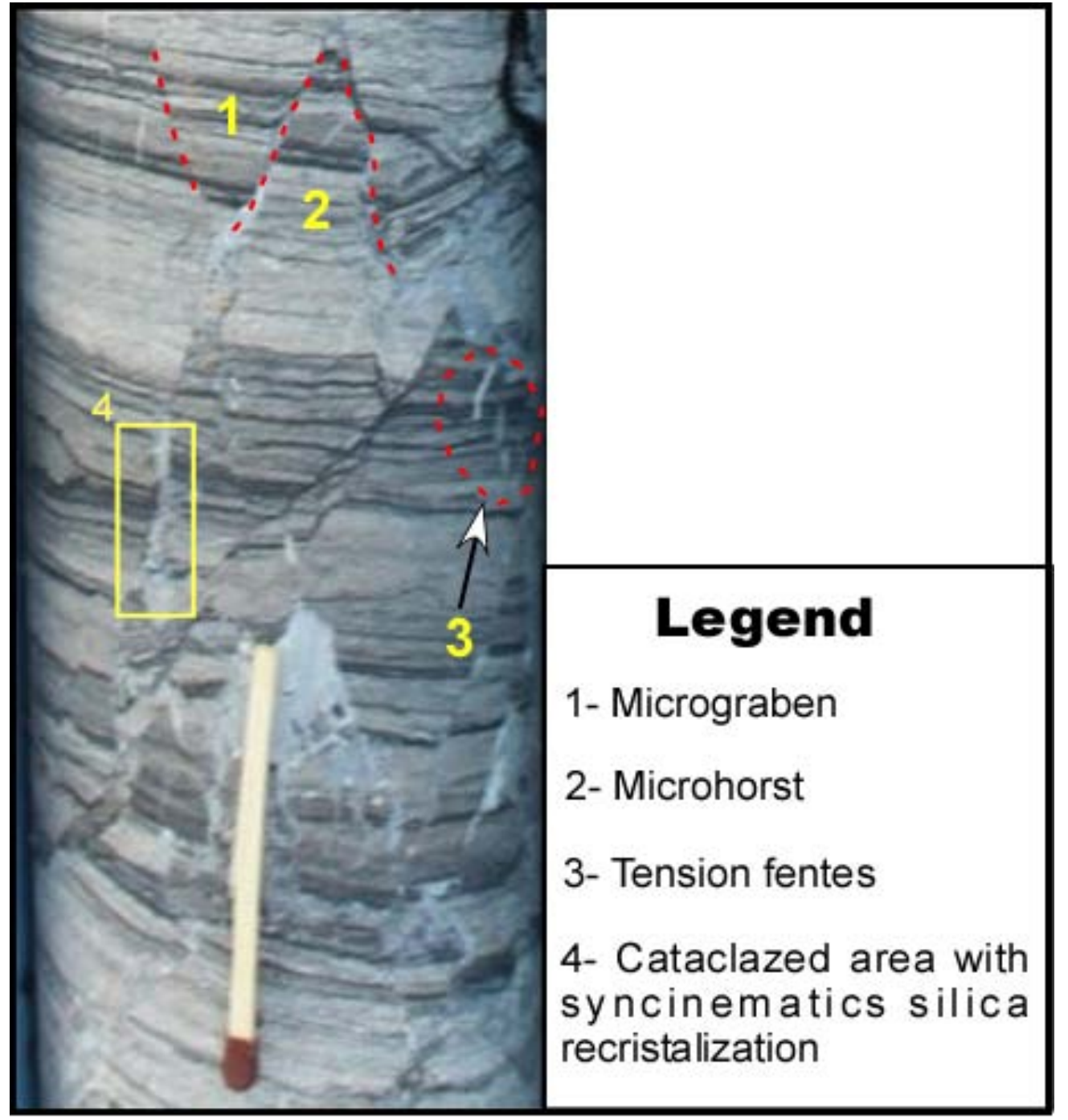

Fig. 28: Carboniferous core sample showing characteristics of post-deposition deformation

\section{Discussion}

Comparing the results of this study to those of Moussa (1992), Cavellec (2006) and Mamane Mamadou et al., (2019), it can be concluded that most of the geological formations of the Tim Mersoï basin identified previously work are also represented in the DASA graben.

\section{a) The Dasa Graben Structure}

To explain the succession of the two phases of the DASA graben structuring (uplift/rifting) over time, the results of this study are compared to those of other African basins, such as Tim Mersoï, Téfidet (North Niger), Benue trough (Nigeria), Muglad basin (Sudan) and others equivalent troughs in North Africa (Libya and Tunisia).

At the regional scale, the DASA graben has the same orientation as the regional strike slip faults system oriented $\sim \mathrm{N} 75^{\circ}$ (Fig. 29), called Agadez Line (Genik,
1992) or the Guinean-Nubian Lineament (GNL) (Guiraud and Bosworth, 1997; Wilson and Guiraud, 1992).

The DASA graben has a singular position between the North troughs (Sirt and Cyrenaica in Libya, in Tunisia) and the South troughs (Benue, Doba, Muglad in the West and Central African Cretaceous rifts called WCARS) (Fig. 29). Most of these rifts (Syrt, Cyrenaica, Gargaf, Termit, Bongor, Doba, Fig. 29) are Cretaceous in age and have a NW-SE to NE-SW trend as has the DASA graben. They thus might have been generated by the same geodynamic event.

During the Carboniferous period a $\mathrm{N} 40^{\circ}$ Visean compression phase has been highlighted in Algeria in the Ougarta area by Blès (1969), in the Béchar Basin by Conrad and Lemosquet (1984), in the Illizi Basin by Boudjema (1987) and in the Ahnet Basin by Zazoun (2001). Furthermore, the Paleozoic time of Libya was represented by the Caledonian orogeny (SilurianDevonian) and resulted in the uplift of the Tripoli-Tibesti uplift along a NW trending direction, and by the 
Hercynian orogeny (Permian-Jurassic) which resulted in the NE trend of the Sirt arch. During the Paleozoic time, the area, where the Sirt basin existing today, an arch existed (Shaaban and Ghoneimi, 2001) which represented one of the old Hercynian NE structures. In the Tim Mersoï basin, too, a N25 horizontal shortening, upper Visean in age, was highlighted by Konaté et al. (2007). During the Visean period, the uplifting observed in the DASA graben indicates that the strike-slip sinistral reactivation of the $N 70^{\circ}$ trending faults has a reverse component. $\mathrm{A} \sim \mathrm{N} 70^{\circ}$ transpressive regime would have affected the DASA graben during this period.

The structural evolution of the DASA graben during the Jurassic-Cretaceous period is compared to those of the West and Central African Rift Systems (WCARS). During the Lower Cretaceous, these rift systems were affected by extensive to transtension tectonics regime (Guiraud et al., 1993, Jing Ye., 2016), favoring a strong rate of subsidence (54 m/Ma for the Termit basin (Liu B et al., 2015), 65 m/Ma for the Muglad Basin (Yassin., 2016), $43 \mathrm{~m} / \mathrm{Ma}$ for the Benue trough (Guiraud., 1992) and $13 \mathrm{~m} / \mathrm{Ma}$ for the Téfidet trough (Konaté et al., 2019). Unlike the Cretaceous rift systems, the DASA graben has a lower subsidence rate (about $6.52 \mathrm{~m} / \mathrm{Ma}$ ). The WCARS that extends from Mali (Gao trough) to Sudan developed in the earlier stages of the Gondwana break-up, i.e., in the Lower Cretaceous (Konaté et al., 2019). Basins in the WCARS are arranged in three main orientations, NE-SW (BenueTrough in Nigeria), ENE-WSW (Doba, Doseo, Salamat basins in eastern Chad and Baggara Basin in western Sudan), and NW-SE (Muglad Basin in Sudan, and the Ténéré rift system in Niger) (Genik, 1993; Yassin et al., 2017). During the Late Jurassic-Early Cretaceous (144.0-112.2 $\mathrm{Ma}$ ) the central Atlantic opened between NW Africa and North America, which caused west movement for the African plate relative to the European plate. E-W trough structures developed in Niger and north Cameroun (Anketell, 1996). During this period continental rifting was active in Africa, affecting the NE Brazil-Gulf of Guinea, southern Chad domain (Doba, Doseo, Salamat basins), the Sudan (Baggara Basin), Kenya N and E Niger and the area of the western desert of Egypt (Abu Gharadig basin) and the southern Sirt basin in Libya (Guiraud and Maurin, 1991). The E-W trending structures of the Sarir and Hameimat troughs in the south east of the Sirt basin coincide with this period. This period was attributed to the collapse of the Sirt Arch, as a result of plate movements along a group of forming basement faults, and failed triple junctions in EW, NW-SE and NE-SW directions (Shaaban and Ghoneimi, 2001). It was associated with deformation in the African plate, which caused development of sedimentary basins within the plate. The tectonosedimentary evolution of the African basins is characterized by polyphase rifting and assumed to be linked to the opening of the south and equatorial
Atlantic. The Sirt basin is one of these basins which developed in this period and is believed to be affected by the opening of the Atlantic Ocean and Tethys Ocean that was formed due to the movement between the Africa and Eurasian plates.

According to this geodynamic context during the Cretaceous period, the extensional tectonic regimes, which affected the DASA graben, could be associated with the opening of the Atlantic that occurred during this period (Genik., 1992, Guiraud et al., 2005, Jing Ye., 2016). 


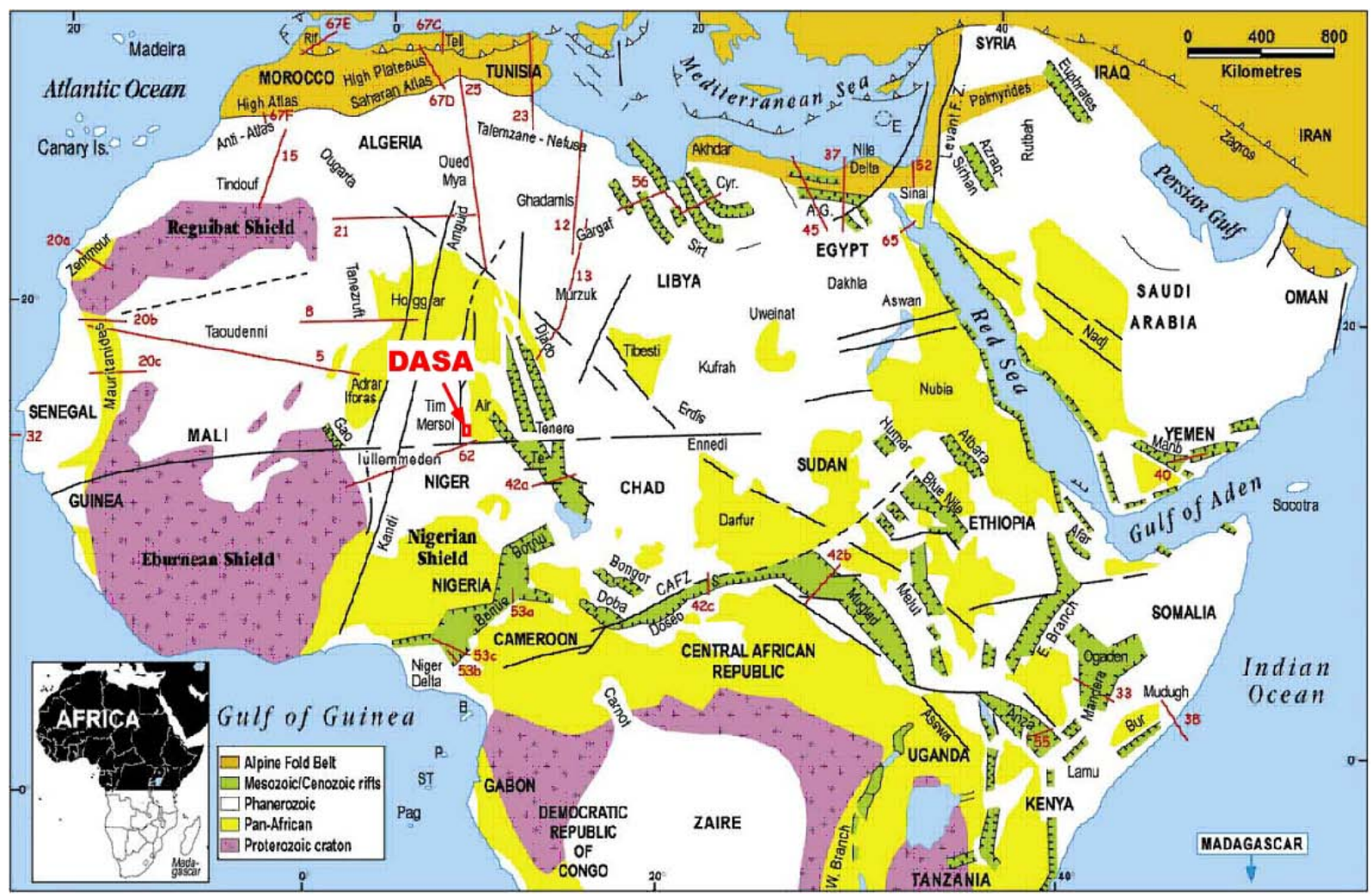

Fig. 29: Schematic geological map of Northeast Africa, Central Africa and Arabia. Compilation of Wilson and Guiraud (1998). The main fault zones and rifts are shown. AG: Abu Gharadig; B: Bioko; CAFZ: Central Africa Fault Zone; CYR: Cyrenaica; SIRTSyrt Basin; E: Eratosthenes island; JP: Jos Plateau; P: Principe; PAG: Pagalu; S: Salamat; ST: São Tomé; TE: Termit; GNL: Guinean-Nubian Lineament; RAG: Raghane shear zone. The red box outlines the location of the DASA graben (Guiraud et al., 2005, modified)

\section{Vili. Uranium Mineralization}

In the Tim Mersoï Basin, the main uranium ore deposits are located in the Tagora and Agadez Groups. In the Visean Tagora Group, the Akouta uranium ore deposit near Arlit is hosted by the Guezouman Formation composed mostly of fluvio-deltaic sandstones, and organic-rich channel formations in general (Forbes, 1989; Cavellec, 2006). The other Arlit ore deposit is found in the Tarat Formation of the Tagora Group, that contains fluvial sandstones and organic-rich clays and silts (Sempéré, 1981; Elhamet, 1983; De Rouvre, 1985; Cavellec, 2006). To the South, the Imouraren uranium ore deposit is located in Tchirezerine 2 Formation of the Upper Jurassic featured by continental arkoses and analcime-rich sandstones (Pacquet, 1969; Valsardieu, 1971; Vallance, 2007; Billon, 2014). All the exploited uranium deposits are located on the eastern side of the Arlit Fault, but uranium ore deposits have also been discovered recently in the western side.

All uranium mineralization, recognized in the Carboniferous and Jurassic-Cretaceous formations of the Tim Mersoï Basin, are also found in the DASA Graben. In addition, at DASA area, uranium mineralization is also recognized in Triassic formations.
Six types of uranium minerals were identified on samples from the Jurassic sediments of the DASA graben. These are the following minerals: Carnotite, Uranophane, Urano-titanate, Coffinite, Torbernite and Autunite.

Compare to the DASA area, the uranium mineral types identified in Arlit area are Uraninite, Coffinite and Urano-Titanate, while Uranophane and Métatyuyaminite are found in the Imouraren region (Forbes, 1989; Mamane, 2016; Mamane M et al., 2019).

In the DASA graben, many factors are involved in the control of the uranium mineralization. These are:

- Lithological factor. Uranium is mainly hosted within the coarser-grained micro-conglomeratic facies of greyish to greenish colored sandstones containing sulfides and organic matter. This characteristic has already been mentioned by Forbes (1989) who shows that organic matter and pyrite bearing sandstones would be a preferential trap for uranium mineralization. Moreover, in the case of the DASA deposit, it also appears that analcime-rich sediments (Triassic to Cretaceous in age) could also be a favorable lithology to the uranium mineralization concentration. This last observation is 
in agreement with the results obtained by Billon (2014) in the Tim Mersoï basin.

- Tectonic factor. Micro-fractures containing uranium were observed in several core samples. Quartz and feldspar contain micro-fractures partially filled with U-oxide. Some samples are intensely cataclastically deformed by high hydrothermal fluid pressure that gives the rock a granitic like appearance. In the Tim Mersoï basin, this hydrothermal fluid flow has been mentioned by Salze (2008). According to Forbes (1989), the creation of the Arlit fault would have favored putting in contact reduced Carboniferous formations with oxidized Permian formations. This spatial arrangement would have favored the concentration of uranium in the Arlit area Carboniferous formations. A similar arrangement has been observed in the DASA graben, where faults created contact between the Triassic-Jurassic formations with the Permian formations (Figs. 3 and 17). Unlike other deposits in the Tim Mersoï basin (0.04 to $0.05 \%$ of uranium grade), in the DASA graben, the higher fracturing density associated with a greater circulation of hydrothermal fluids have favored a higher grade (1\% on average) of uranium mineralization (Global Atomic Corporation, 2018).

The tectonic peculiarities of the DASA area are also responsible that the DASA deposit is unique amongst all the known uranium deposits of Niger as it contains itself all the major uranium bearing formations which are either mined or will be mined elsewhere in the Tim Mersoi basin. In the Arlit mining area all formations younger than Permian no longer exists and for the Imouraren area little is known about any mineralization in the Carboniferous.

\section{iX. Conclusion}

The tectono-sedimentary and microtectonic analysis suggests that the DASA graben was affected by two major structuring periods.

- The first period was an uplifting stage that prevailed during the Carboniferous-Permian times. It was marked by a $\sim \mathrm{N} 70^{\circ}$ transpressive tectonic regime.

- The second period was a rifting stage that occurred during the time ranging from the Triassic to the Lower Cretaceous. This period was mainly characterized by a $\sim \mathrm{N} 160^{\circ}$ extensional regime.

Lithological and tectonic features have controlled the formation of uranium mineralization in the DASA graben.

From a lithological point of view, uranium is mainly hosted within coarse-grained sandstones, containing sulfides and organic matter in Carboniferous deposits or analcime in Triassic to Cretaceous deposits. This study has also shown that successive fracturing phases that affected the DASA graben over time played an important role in the emplacement of the mineralization. This intense fracturing observed in core samples is associated with fracture infilling of sediments with high to very high-grade of uranium mineralization.

\section{ACKNOWLeDgements}

The authors are grateful to and acknowledge the efforts of Global Atomic Corporation Staff for their collaboration and technical support. The authors are also grateful to Stephan Roman, Chairman of Global Atomic Corporation, for financial support. Sincere thanks to the reviewers for their observations and comments.

\section{References Références Referencias}

1. Anketel, J,M., 1996. Structural history of the Sirt Basin and its Relationships to the Sabratah Basin and Cyrenaican Platform, Northern Libya. ELSEVIER $3: 57-87$.

2. Billon, 2014. Minéraux argileux dans le gisement uranifère d'Imouraren (Bassin de Tim Mersoï, Niger): implications sur la genèse du gisement et sur l'optimisation des processus de traitement du minerai. Thèse Terre solide et enveloppes superficielles. Poitiers: Université de Poitiers, 2014. http://theses.univ-poitiers.fr.

3. Blès, J.L.,1969. Les relations des microfractures avec le plissement dans la région du Djebel Ben Tadjine et au 'km 30' (Chaînes d'Ougarta-Sahara occidental, Algérie). Publication Service Géologique Algérie 39, 193-204.

4. Boudjema, A., 1987. Évolution structurale du bassin pétrolier 'triasique' du Sahara Nord Oriental (Algérie). Thèse Doctorat Etat, Paris XI-Orsay, France, 290p.

5. Cavellec, S., 2006. Evolution diagénétique du bassin de Tim Mersoï (district Arlit-Akokan, Niger) [Ph.D. thesis]: Université de Paris-Sud, 450 p.

6. Cazoulat M., 1985. Geologic environment of the Uranium deposits in the Carboniferous and Jurassic sandstones of the Western margin of the Air mountains in the Republic of Niger. In: "Geological environments of sandstone-type uranium deposits", FINCH. W.I. \& al. eds.-IAEA-TECDOC 328, Vienna, p.247-263.

7. Clermonté et al. 1991. Un bassin paléozoïque et mésozoïque dans une zone en décrochement : le Tim Mersoï dans la région d'Arlit, à l'Ouest de I'Aïr (Niger). - C.R. Acad. Sc. Fr., Paris, t.312, Série II, p.1189-119.

8. Conrad, J., et Lemosquet, Y., 1984. Du craton vers sa marge : évolution sédimentaire et structurale du bassin Ahnet-Timimoun-Béchar (Sahara algérien) au cours du Carbonifère. Données paléoclimatiques. Bulletin Société Géologique France, Série 7 , 26 (6), 987-994. 
9. De Rouvre, I., 1985. Contribution à l'étude de la flore paléozoïque de la bordure occidentale de l'Aïr (République du Niger) [Ph.D. thesis]: Université de Paris VI, $380 \mathrm{p}$.

10. Elhamet, M.O., 1983. Analyse géologique et pétrographique de la formation de Tarat dans les carrières Somaïr (Paléozoïque supérieur). Essai d'interprétation paléoclimatique à la lumière de l'épisode glaciaire dévono-carbonifère (Région d'Arlit - Niger septentrional) [Ph.D. thesis]: Université de Dijon (France) et Université de Niamey (Niger), $279 \mathrm{p}$.

11. Forbes, P., 1989. Rôles des structures sédimentaires et tectoniques, du volcanisme alcalin régional et des fluides diagénétiqueshydrothermaux pour la formation des minéralisations à U-Zr- Zn-V-Mo d'Akouta (Niger) : mémoire édité par le Centre de Recherches sur la Géologie de l'Uranium (CREGU), Nancy, v. 17, $376 \mathrm{p}$.

12. Jing Ye, 2016. Évolution Topographique, Tectonique et Sédimentaire Syn- à Post-rift de la Marge Transformante Ouest Africaine. Sciences de la Terre. Université toulouse 3 Paul Sabatier, 2016. Français. tel-01419963.

13. Joulia, 1959. Les séries primaires au N et au NW de l'Aïr (Sahara central). Discordances observées. Bull. Soc. géol. Fr., p.192-196.

14. Lui B et al. 2015. Hydrocarbon potential of upper cretaceous marine source rocks in the Termit Basin, Niger. Journal of Petroleum Geology, Vol. 38(2), April 2015, pp 157-176.

15. Genik., 1993. Petroleum geology of CretaceousTertiary rift basins in Niger, Chad and Central African Republic. - AAPG Bulletin, 77, 1405-1434.

16. Genik, G. J., 1992. Regional framework, structural and petroleum aspects of rift basins in Niger, Chad and the Central African Republic (C.A.R.): Tectonophysics, v. 213, p. 169-18.

17. Gerbeaud, O., 2006. Evolution structurale du Bassin de Tim Mersoï : Déformations de la couverture sédimentaire, Relations avec la localisation des gisements d'uranium du secteur d'Arlit (Niger). Thèse de doctorat Université de Paris-Sud UFR scientifique d'Orsay, 270 pages.

18. Guiraud, R., Bosworth W., 1997. Senonian basin inversion and rejuvenation of rifting in Africa and Arabia: synthesis and implications to plate-scale tectonics. Tectonophysics 282, 39-82.

19. Guiraud, R., 1993. Early Cretaceous rifts of West and Central Africa: an overview. - Tectonophysics, 213, 153-168.

20. Guiraud, R., Maurin, J.C., 1992. Early Cretaceous rifts of Western and Central Africa: an overview. Tectonophysics, 213: 153-168.

21. Guiraud et Maurin., 1991. Le rifting en Afrique au Crétacé inférieur, synthèse structurale, mise en évidence de deux étapes dans la genèse des bassins, relations avec les ouvertures océaniques péri panafricaines. - Bulletin de la Société géologique de France, 162, 811-823.

22. Guiraud, R., Bosworth, W., Thierry, J., and Delplanque, A., 2005. Phanerozoic geological evolution of Northern and Central Africa: An overview, J. Afr. Earth Sci., 43, 83-143, https://doi.org/10.1016/j.jafrearsci.2005.07.017, 2005.

23. Guiraud, R et al., 1981. Mise en évidence de déformations traduisant un raccourcissement dans le Mésozoïque de la périphérie de l'Aïr (Niger). Compte rendu de l'Accadémie des Sciences de Paris, 282 (II): 753-756.

24. Konaté, M., Yacouba, A et Moussa, H., 2019. Structural evolution of the Téfidet trough (East Air, Niger) in relation with the West African Cretaceous and Paleogene rifting and compression episodes, Comptesrendus - Geoscience, https://doi.org/ 10.1016/j.crte.2018.11.009.

25. Konaté, M., Denis, M., Yahaya, M., and Guiraud, M., 2007. Structuration extensive au devono-dinantien du bassin de Tim Mersoï (Bordure occidentale de l'Aïr, Nord Niger). Publié dans: Université de Ouagadougou, Annales, Série C, v. 005, 32 p.

26. Mamane, M., 2019. Cenozoic oxidation episodes in West Africa at the origin of the in situ supergene mineral redistribution of the primary uranium ore bodies (Imouraren deposit, Tim Mersoï Basin, Northern Niger), Mineralium deposita. https://doi.org/10.1007/s00126-019-00945-w.

27. Mamane, M., 2016. Le système métallogénique des gisements d'uranium associé à la faille d'Arlit (Bassin de Tim Mersoï, Niger): diagenèse, circulation de fluides et mécanismes d'enrichissement en métaux $(U, C u, V)$. Thèse de doctorat Université de Lorraine, 402 pages.

28. Moussa, Y., 1992. Dynamique sédimentaire du Guézouman et des formations viséennes sousjacentes en liaison avec la tectonique, le volcanisme et le climat, paléomilieux des gîtes uranifères d'Arlit (Niger). Thèse Doctorat troisième cycle, Université de Dijon, $357 \mathrm{p}$.

29. Pacquet, A., 1969. Analcimes et argiles diagénétiques dans les formations sédimentaires de la région d'Agadès (République du Niger) [Ph.D. thesis]: Université de Strasbourg, 258 p.

30. Salze, 2008. Etude des interactions entre uranium et composés organiques dans les systèmes hydrothermaux. Thèse de l'université de Nancy, 316p.

31. Sani, A., Konaté, M., Karimou, D. H. and Wollenberg, P., 2020. Polyphasic tectonic history of the N70 DASA Graben (northern, Niger). Global Journal of Earth and Environmental Science,

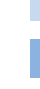


Volume 5(3), Pages 58-72.https://doi.org/10.31248/ GJEES2020.075.

32. Shaaban, F. F. and A. E. Ghoneimi., 2001. Implication of seismic and borehole data for the structure, petrophysical and oil entrapment of Cretaceous-Paleocene reservoirs, northern Sirt basin, Libya. Journal of African Earth Sciences. 33 : 103-133.

33. Sempéré, T., 1981. Le contexte sédimentaire du gisement d'uranium d'Arlit (République du Niger). Thèse de doctorat, ENSMP, Paris, 382 pp.

34. Sempéré et Beaudoin., 1981. Discontinuités et séquences dans la formation de Tarat (Viséen supérieur) et l'unité d'Arlit (Namuro-Westphalien) à Arlit (Niger). Evolution sédimentaire, climatique et tectonique de la région au Carbonifère. Bulletin de la Société Géologique de France, 296 (6): 995-1014.

35. Tarek, S, Elakkari., 2005. Structural evolution of the Sirt basin.

36. TAUZIN P., (1981). Cadre géologique des gisements d'uranium de la bordure orientale du bassin sédimentaire du Tim Mersoï. - Rapport interne Minatome, $15 \mathrm{p}$.

37. Valsardieu, C., 1971. Etude géologique et paléogéographique du bassin de Tim Mersoï, région d'Agadès (République du Niger). Thèse de doctorat, université de Nice, 518 pp.

38. Vallance, J., 2007. Modèle métallogénique du gisement d'Imouraren (Niger): Rapport Postdoctorat du centre de recherches sur la géologie des matières premières minérales et énergétiques, $150 \mathrm{p}$.

39. Wagani, I., 2007. Potentialités uranifères des sources volcaniques envisageables pour la formation des minéralisations de la région d'Arlit (Niger). Thèse de l'université de Paris Sud, 291 p.

40. Wilson, M., Guiraud, R., 1992. Magmatism and rifting in Western and Central Africa, from Late Jurassic to Recent times. Tectonophysics 213, 203-225.

41. Wright, Li., 1989. Etude du bassin houiller d'Anou Araren -Solomi, Phase 1: Etude des données; Charbon de l'Airr, Charbonnages de France avec British Mining Consultants Ud., 21- 41-51 pp.

42. Yassin M. A et al., 2017. Evolution history of transtensional pull-apart, oblique rift basin and its implication on hydrocarbon exploration: A case study from Sufyan Sub-basin, Muglad Basin, Sudan. Marine and Petroleum Geology 79, 282-299.

43. Yassin, 2016. Evolution history of transtensional pull-apart, oblique rift basin and its implication on hydrocarbon exploration: A case study from Sufyan Sub-basin, Muglad Basin, Sudan. www.elsevier. com/locate/marpetgeo.

44. Zazoun, 2001. La tectogenèse hercynienne dans la partie occidentale du bassin de l'Ahnet et la région de Bled El-Mass, Sahara algérien : un continuum de déformation. Journal of African Earth Science, vol. 32, No. 4, 869-887. 